\title{
BRYANSK-KURSK-VORONEZH INTRA-CONTINENTAL COLLISIONAL OROGEN (EAST EUROPEAN CRATON)
}

\author{
M. V. Mints ${ }^{1}$, W. A. Bush ${ }^{2}$, S. N. Ageev² \\ ${ }^{1}$ Geological Institute of RAS, Moscow, Russia \\ ${ }^{2}$ Aerogeophysica Inc., Moscow, Russia
}

\begin{abstract}
The article presents new data on the deep crustal structure, origin and evolution of the Bryansk-Kursk-Voronezh orogen in the south-eastern segment of the East European craton; it is composed of the Paleoproterozoic formations and areas of reworked Archean crust. The purpose of this paper is the development and improvement of ideas on intra-continental orogens. The deep structure of the orogen is presented by the 3D model based on results of geological mapping of the Precambrian basement and interpretations of geophysical fields and seismic images of the crust along geotraverse 1-EB and profile DOBRE. It is established that the orogen originated with riftogenic extension of the crust at $2.6-2.5 \mathrm{Ga}$, that was repeated at 2.2-2.1 Ga, and formation of wide depressions that were efficiently filled in with volcanosedimentary layers including BIF, which accumulation was followed by high-temperature up to granulite facies metamorphism. Suprasubduction magmatism took place at 2.10-2.08 Ga and resulted in formation of the Lipetsk-Losevka volcano-plutonic complex. The active margin was completely formed at about $2.05 \mathrm{Ga}$. The short duration of subduction-related magmatic activity and the lack of relics of the oceanic lithosphere suggest short-term and spatially limited developing of the oceanic structure. The tectonothermal activity of collisional and postcollision stages was expressed in emplacement of alkaline ultramafic (2.1-2.0 Ga) and gabbrosyenite $(1.8-1.7 \mathrm{Ga})$ complexes. It is difficult or impossible to explain specific features of the structure and evolution of the orogen in framework of the model of the Cordilleras type accretionary orogen. Mafic-ultramafic magmatism and indications of intensive heating of the crust suggest a special role of plume type processes that provided for influx of mantle heat and juvenile mantle derived matter.
\end{abstract}

Key words: East European craton, Voronezh crystalline massif, intra-continental orogen, East Voronezh orogen, Paleoproterozoic, Losevka series, Vorontsovka series.

Recommended by V.S. Fedorovsky

Citation: Mints M.V., Bush W.A., Ageev S.N. 2014. Bryansk-Kursk-Voronezh intra-continental collisional orogen (East European craton). Geodynamics \& Tectonophysics 5 (3), 717-742. doi:10.5800/GT-2014-5-3-0151.

\section{БРЯНСК-КУРСК-ВОРОНЕЖСКИЙ ВНУТРИКОНТИНЕНТАЛЬНЫЙ КОЛЛИЗИОННЫЙ ОРОГЕН (ВОСТОЧНО-ЕВРОПЕЙСКИЙ КРАТОН)}

\author{
М. В. Минц ${ }^{1}$, В. А. Буш ${ }^{2}$, С. Н. Агеев ${ }^{2}$ \\ ${ }^{1}$ Геологический институт РАН, Москва, Россия \\ 2 ЗАО «ГНПП Аэрогеофизика», Москва, Россия
}

Аннотация: Приведены новые данные, характеризующие глубинное строение, зарождение и эволюцию БрянскКурск-Воронежского орогена (юго-восточная часть Восточно-Европейского кратона), образованного палеопротерозойскими комплексами и областями переработанной архейской коры. Целью статьи является развитие и совершенствование представлений о внутриконтинентальных орогенах. Глубинное строение орогена представлено в виде объемной модели, суммирующей результаты геологического картирования докембрийского фундамента, интерпре- 
тации геофизических полей и сейсмических образов коры по геотраверсу 1-EB и профилю DOBRE. Зарождение будущего орогена зафиксировано рифтогенным растяжением коры 2.6-2.5 млрд лет и повторно 2.2-2.1 млрд лет назад и возникновением обширных депрессий, быстро заполнявшихся вулканогенно-осадочными толщами, включая железисто-кремнистые осадки, которые вслед за накоплением оказывались в условиях высокотемпературного (до гранулитовой фации) метаморфизма. Надсубдукционный магматизм, результатом которого стало формирование ЛипецкоЛосевского вулканоплутонического комплекса, связан с интервалом 2.10-2.08 млрд лет. Формирование активной окраины завершилось около 2.05 млрд лет назад. Кратковременность надсубдукционного магматизма и отсутствие реликтов океанической литосферы свидетельствуют о кратковременном и локализованном в пространстве существовании океанической структуры. Тектонотермальная активность коллизионного и постколлизионного этапов проявилась в размещении массивов щелочных пород щелочно-ультраосновной (2.1-2.0 млрд лет) и габбро-сиенитовой (1.8-1.7 млрд лет) формаций. Особенности строения и эволюции орогена трудно или невозможно объяснить в рамках модели аккреционных орогенов кордильерского типа. Мафит-ультрамафитовый магматизм и свидетельства интенсивного прогрева коры указывают на особую роль процессов плюмового типа, обеспечивавших притоки мантийного тепла и ювенильного вещества.

Ключевые слова: Восточно-Европейский кратон, Воронежский кристаллический массив, внутриконтинентальный ороген, Восточно-Воронежский ороген, палеопротерозой, лосевская серия, воронцовская серия.

\section{1. ВВЕДЕНИЕ}

Ранее было показано [Mints et al., 2010], что многие особенности палеопротерозойских тектонических структур Восточно-Европейского кратона (BEK), образующего фундамент одноименной платформы, позволяют рассматривать эти структуры в качестве внутриконтинентальных коллизионных орогенов (в понимании [Cawood et al., 2009]). Анализ материалов, характеризующих неоархейские и протерозойские орогены северной половины BEK и Лавроскандии в целом, позволил развить и значительно расширить представления о значимости и роли подобных орогенов в эволюции раннедокембрийской коры. Было установлено, что эти орогены целесообразно рассматривать в качестве нового типа концентрически-зональных тектонических сооружений регионального и надрегионального ранга внутриконтинентальных овальных орогенов.

В той же работе [Mints et al., 2010] было показано, что особенности строения средне-палеопротерозойского внутриконтинентального орогена в восточной части Сарматии, который был назван Брянск-Курск-Воронежским, не в полной мере соответствуют выделенному типу тектонических структур, как по размеру, так и по морфологии.

Цели предлагаемой статьи включают: 1) усовершенствование модели глубинного строения восточного крупного сегмента ВEK, названного Сарматией [Bogdanova et al., 2005], объединяющего Воронежский кристаллический массив (ВКМ) и восточную часть Украинского щита (УЩ), и 2) развитие и совершенствование представлений о внутриконтинентальных орогенах. В статье приведены новые данные, характеризующие глубинное строение и эволюцию Брянск-КурскВоронежского орогена. Северная часть этого орогена находится в пределах ВКМ, а южная часть меньшего размера - в восточной части УЩ. Ороген образован ранне- и средне-палеопротерозойскими комплексами и включает области архейской коры, переработанной в палеопротерозое (рис. 1). Внешние очертания орогена определяются конфигурацией тектонических структур, возникших уже после его формирования - преимущественно к концу палеопротерозоя. В пределах этих границ протяженность Брянск-Курск-Воронежского орогена с севера на юг - в направлении простирания орогенов второго порядка и разделяющих их тектонических границ - достигает 800 км, ширина - более 800 км. Одним из главных компонентов Брянск-КурскВоронежского внутриконтинентального орогена является Восточно-Воронежский ороген второго порядка [Mints et al., 2010], глубинное строение которого детально исследовано с применением сейсмопрофилирования МОВ-ОГТ (МОГТ). Характеристике глубинного строения Восточно-Воронежского орогена мы уделим особое внимание.

Выполненные в разные годы палеотектонические реконструкции зарождения и эволюции средне-палеопротерозойского орогена в восточной части Сарматии последовательно опирались на сменявшие друг друга глобальные геодинамические концепции. Были, в частности, предложены следующие модели:

- эволюции палеопротерозойской геосинклинальной области, облекавшей архейские срединные массивы, особенности размещения которых определяли своеобразие условий осадконакопления и тектонического развития [Polishchuk et al., 1970];

- стадийного развития континентальной коры, где с палеопротерозоем связывались процессы преобразования архейской коры: обособление и развитие сводовых поднятий (гнейсовых «овоидов») и межсводовых линейных зон и сланцевых поясов, частью рифтогенного характера, и в итоге - формирование «зрелой» континентальной коры [Bogdanova, 1986];

- эволюции тектоноплитного типа, начавшейся с 


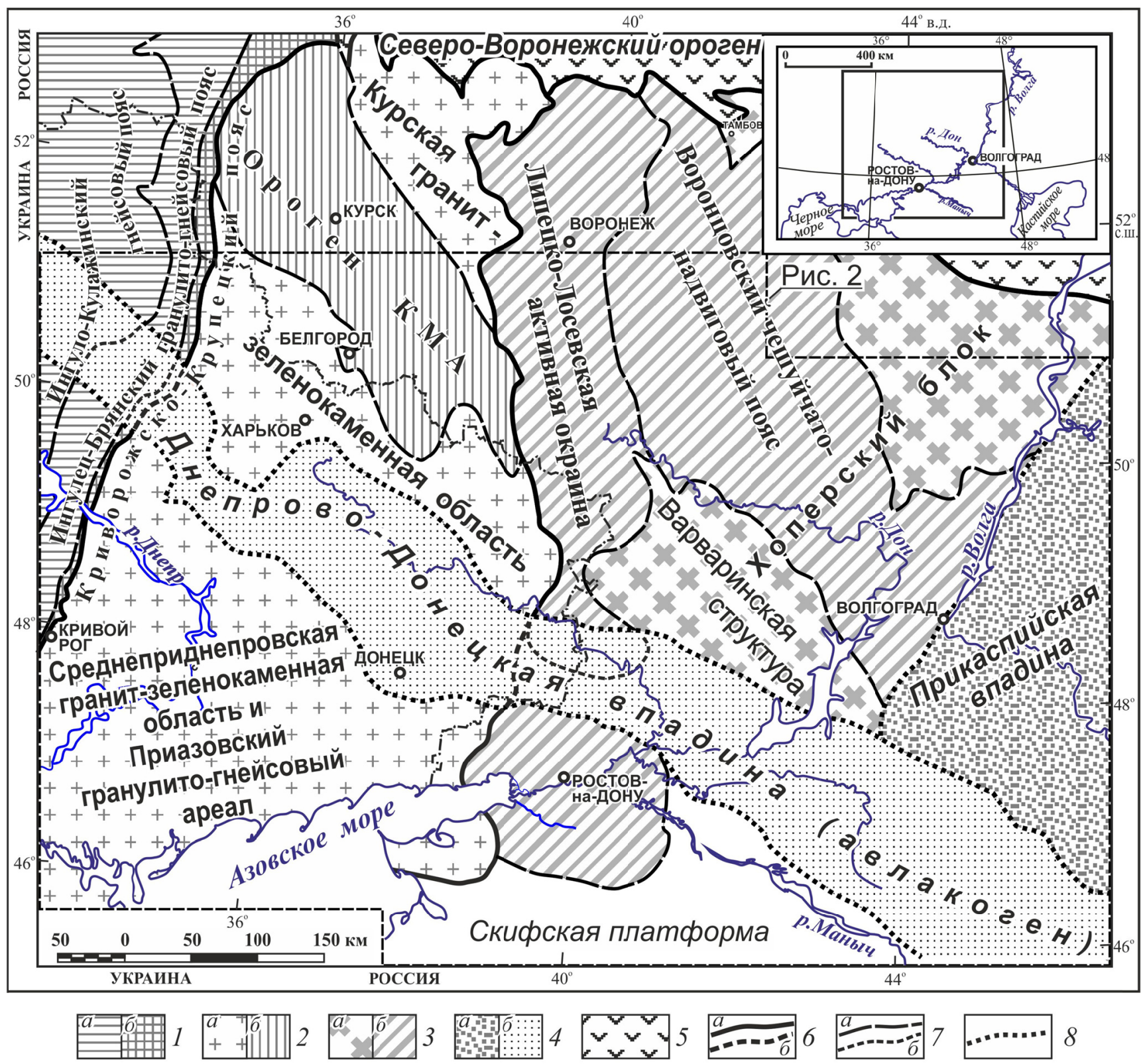

Рис. 1. Схема тектонического районирования средне-палеопротерозойского Брянск-Курск-Воронежского внутриконтинентального коллизионного орогена.

Шрифты в наименованиях тектонических структур: ариал - частично переработанная архейская кора, таймс-нью-роман - средне-палеопротерозойские тектонические пояса и орогены, ариал-италик - позднепалеопротерозойские и более молодые структуры. 1 - Криворожско-Брянский ороген: $a$ - амфиболит-гнейсовые и гранулито-гнейсовые комплексы, $\sigma$ - гранит-зеленокаменные комплексы, интенсивно деформированные совместно с палеопротерозойскими железорудными поясами; 2 - ороген Курской магнитной аномалии (КМА): $a$ - архейские гранит-зеленокаменные и гранулито-гнейсовые комплексы, частично переработанные в палеопротерозое, 6 - совместнодеформированные в палеопротерозое железорудные пояса и вмещающие архейские гранит-зеленокаменные комплексы; 3 - ВосточноВоронежский ороген: $a$ - архейские комплексы Хоперского блока, $\sigma$ - Липецко-Лосевская активная окраина и Воронцовский чешуйчатонадвиговый пояс; 4 - фанерозойские впадины: $a$ - Прикаспийская, $\sigma$ - Днепрово-Донецкая; 5 - позднепалеопротерозойский СевероВоронежский ороген; 6-8 - границы: 6 - орогенов, перекрытые: $a$ - платформенным чехлом, 6 - толщей, заполняющей ДнепровоДонецкую впадину, 7 - тектонических поясов: $a$ и 6 - аналогично предыдущему, 8 - фанерозойских впадин.

Fig. 1. Tectonic zoning scheme of the Middle Paleoproterozoic Bryansk-Kursk-Voronezh intra-continental collisional orogen.

Names of tectonic structures: Arial font - partially reworked Archean crust; Times New Roman - Middle Paleoproterozoic tectonic belts and orogens; Arial italics - Late Paleoproterozoic and younger structures. 1 - Krivoy Rog-Bryansk orogen: $a$ - amphibolite-gneiss complexes, $\sigma$ - granite-greenstone complexes intensively deformed jointly with the Paleoproterozoic BIF belts; 2 - Kursk magnetic anomaly (KMA) orogen: $a$ - Archean granite-greenstone and granulite-gneiss complexes partially metamorphosed in the Paleoproterozoic, $\sigma$ - BIF belts and host Archean granite-greenstone that were jointly deformed in the Paleoproterozoic; 3 - East Voronezh orogen: $a$ - Archean complexes of the Khoper block, $\sigma$ Lipetsk-Losevka active margin and Vorontsovka imbricated thrust belt; 4 - Phanerozoic depressions: $a$ - Peri-Caspian, $\sigma$ - Dnieper-Donets; 5 Late Paleoproterozoic North Voronezh orogen; 6 - boundaries of orogens covered by: $a$ - platform cover, $\sigma$ - sediments filling Dnieper-Donets depression, 7 - boundaries of tectonic belts: $a$ and $\sigma$ - same as above, 8 - boundaries of Phanerozoic depressions. 
раскола (рифтогенеза) архейского континента и завершившейся коллизией восточной окраины Сарматии с Волго-Уральским (Воронежско-Куйбышевским) континентом [Chernyshov et al., 1997].

- тектоноплитной эволюции восточной окраины Сарматии и формирования Восточно-Сарматского аккреционного орогена вдоль границы Сарматии с обширной палеоокеанической областью [Shchipansky et al., 2007].

Развитием модели Н.М. Чернышова с соавторами [1997] явилось представление о геодинамической эволюции взаимозависимых латерально распределенных (образующих закономерный латеральный ряд) тектонических структур - от Кулажинского и Брянского гранулито-гнейсовых поясов на западе до Воронцовской чешуйчатой надвиго-поддвиговой структуры на востоке [Rundquist et al., 1999; Mints et al., 2010].

Анализ широкого круга данных, включая региональные геофизические материалы и характеристику глубинного строения по профилям 1-EB и DOBRE, позволил на новом уровне вернуться к исследованию глубинного строения и охарактеризовать историю зарождения и эволюции Брянск-Курск-Воронежского орогена и на этой основе расширить существующие представления о внутриконтинентальных орогенах.

\section{2. ГЕОЛОГИЧЕСКИЙ ОЧЕРК}

\section{1. АРХЕЙСКАЯ КОРА ВОСТОЧНОЙ ЧАСТИ САРМАТИИ}

В строении архейской континентальной коры восточной части Сарматии, частично преобразованной палеопротерозойскими процессами, определяющую роль играют гранит-зеленокаменные и гранулитогнейсовые структурно-вещественные ассоциации (рис. 1). Архейские структурно-вещественные ассоциации Среднеприднепровской гранит-зеленокаменной области (ГЗО) и Приазовской провинции УЩ образованы однотипными и близкими по возрасту палеомезоархейскими гнейсовидными и массивными гранитоидами и зеленокаменными осадочно-вулканогенными комплексами, датированными интервалом 3.6-2.9 млрд лет [Shcherbakov, 2005; Shcherbak et al., 2009]. Курская ГЗО в пределах ВКМ образована аналогичными по составу и уровню метаморфизма комплексами пород, возраст которых (3.4-2.9 млрд лет) в пределах точности совпадает с предыдущим [Mints et al., 2010, and references therein]. В строении Приазовской провинции УЩ преобладают породы гранулитовой фации метаморфизма [Kolosovskaya, 1992; Shcherbakov, 2005]. Meтаосадочные гранулиты подстилаются гранит-зеленокаменными ассоциациями, которые неравномерно метаморфизованы в условиях гранулитовой фации или сохраняют признаки реликтовых минеральных парагенезисов этой фации. Эти ассоциации обычно рассматривают в качестве «комплекса основания» (например,
[Lobach-Zhuchenko et al., 2010a]).

К моменту проявления метаморфизма гранулитовой фации и образования Приазовского гранулито-гнейсового ареала (ГГА) около 3.0 млрд лет назад [LobachZhuchenko et al., 2010b] гранит-зеленокаменная кора в восточной части УЩ уже представляла собой единую континентальную массу. Меньший по размеру КурскоБесединский ГГА в центральной части Курской ГЗО был сформирован около 2.85 млрд лет.

\section{2. СРЕДНЕПАЛЕОПРОТЕРОЗОЙСКИЙ БРЯНСК-КУРСК- ВОРОНЕЖСКИЙ ВНУТРИКОНТИНЕНТАЛЬНЫЙ КОЛЛИЗИОННЫЙ ОРОГЕН}

Строение орогена определяется его возникновением и развитием в пределах обширной области архейской континентальной коры, образованной гранитзеленокаменными и гранулито-гнейсовыми ассоциациями, и представлено латеральной последовательностью субмеридиональных орогенов второго порядка (рис. 1).

Орогены второго порядка, в свою очередь, включают структуры тектонических поясов. С запада на восток следуют: Криворожско-Брянский ороген, ороген Курской магнитной аномалии (КМА) и ВосточноВоронежский ороген (рис. 2). Последний можно рассматривать в качестве осевой (центральной) структуры Брянск-Курск-Воронежского орогена, поскольку его размещение фиксирует область кратковременного разрыва континентальной коры.

Криворожско-Брянский ороген протягивается в меридиональном направлении вдоль западных окраин Курской и Среднеприднепровской ГЗО (рис. 1, 2). Образующие кору петроплотностные и петромагнитные объекты были выделены на основе региональных геофизических полей с использованием методов интерпретации, принятых в ЗАО «Аэрогеофизика» [Babayants et al., 2003, 2004]. Эти объекты отвечают определенным структурно-вещественным комплексам, в частности их асимметрия и срезание одних элементов другими позволяют с определенной уверенностью реконструировать покровную чешуйчато-надвиговую структуру северной части орогена. Тектонические пояса, образующие этот ороген, уверенно трассируются в пределы Ингуло-Ингулецкого (Кировоградского) блока УЩ, следуя границам геофизических полей (см. в [Mints et al., 2010; Pigulevsky, 2012]).

Западная часть Криворожско-Брянского орогена образована тектоническими покровами Ингуло-Кулажинского гнейсового и Ингулец-Брянского гранулитогнейсового поясов. Восточная зона включает Крупецко-Знаменский пояс, в строении которого значительную роль играют интенсивно деформированные железорудные комплексы. Этот пояс представляет собой чешуированную западную окраину архейского Курского кратона. Непосредственным продолжением Крупецко-Знаменского пояса на территории УЩ является 
Криворожский пояс, который протягивается вдоль окраины Среднеприднепровской гранит-зеленокаменной области. Характерной особенностью КриворожскоБрянского коллизионного орогена является встречное перемещение тектонических покровов, в результате которого была сформирована общая антиформная («гребневидная») структура орогена в целом.

Ингуло-Кулажинский гнейсовый пояс прослеживается с севера на юг на протяжении более 600 км при ширине около 200 км. В строении пояса преобладают глиноземистые гнейсы (метаосадки) гранулитовой фации с небольшим участием амфиболитов. Значительная мощность метаосадков, изотопно-геохимические признаки вовлечения древнего континентального источника сноса и особенности состава метаосадков позволяют предполагать, что осадконакопление (формирование протолита гнейсов) протекало в пределах эпиконтинентального бассейна, окруженного областью со слаборасчлененным рельефом и интенсивно проявленными процессами химического выветривания [Rosen et al., 2006]. Оценки параметров метаморфизма отвечают переходной зоне между высокотемпературной амфиболитовой и гранулитовой фациями: 690-720 ${ }^{\circ} \mathrm{C}$ и 7.5-8.0 кбар [Savko, 1999]. В южной части пояса в пределах УЩ оценки температур метаморфизма достигают $800{ }^{\circ} \mathrm{C}$ при аналогичных или несколько более низких давлениях [Shcherbakov, 2005]. В составе осадочного протолита преобладали продукты денудации архейского основания, возраст гранулитового метаморфизма - 2.13 млрд лет, возраст последовавшей мигматизации - около 2.05 млрд лет [Claesson et al., 2001; Rosen et al., 2006].

Ингулец-Брянский гранулито-гнейсовый пояс протягивается с севера на юг более чем на 600 км при ширине около 50 км. Высокий уровень магнитного поля над этим поясом определяется значительным участием в разрезе магнетитовых кварцитов и эвлизитов (магнетит-силикатных пород). Пиковые параметры гранулитового метаморфизма равны 800-850 ${ }^{\circ} \mathrm{C}$ при давлении 5.5-6.0 кбар [Savko, 1999].

Крупецко-Знаменский пояс протягивается в меридиональном направлении, образуя с Ингулец-Брянским гранулито-гнейсовым поясом структурно согласованную тектоническую систему (рис. 1, 2). Крупецко-Знаменский пояс является непосредственным продолжением расположенного южнее Криворожского пояса. Ширина обоих поясов, как правило, составляет 10-15 км, суммарная протяженность превышает 600 км. Пояс отличается более низким уровнем метаморфизма и, по существу, представляет собой интенсивно деформированную окраину архейского Курского кратона. Восточная граница пояса намечается с определенной условностью, так как уровень деформаций снижается в восточном направлении скачкообразнопостепенно.

Ороген Курской магнитной аномалии (KMA). В строении орогена главную роль играют железорудные вулканогенно-осадочные пояса (рис. 1, 2). Второй по значимости компонент представлен субвулканическими и интрузивными комплексами мафит-ультрамафитового, кислого и щелочного состава. С заключительной стадией эволюции связано формирование гранитогнейсовых куполов.

Железорудные вулканогенно-осадочные пояса характеризуются преимущественно северо-западным простиранием (рис. 1, 2). Они представлены ассоциацией протяженных (до 100 км и более) тектонических чешуй небольшой мощности и пологих асимметричных структур синклинального строения шириной от 20 до 50 км, частично сорванных с архейского основания. Глубина залегания подошвы крупных синформ по геофизическим данным оценивается в 5-8 км. Пологие юго-западные крылья синформ в большей степени сохраняют участки нормального стратиграфического контакта с породами архейского основания, тогда как северо-восточные крылья нередко запрокинуты и/или перекрыты надвинутыми в юго-западном направлении породами архейского гранит-зеленокаменного комплекса. Северо-восточные крылья Белгородской и Михайловской синформ нарушены овальными структурами гранитогнейсовых куполов. Близ западной границы орогена железорудные пояса меняют северозападное простирание на субмеридиональное, согласованное с простиранием границы между орогенами. Перерыв тектонической активности, предшествовавший формированию палеопротерозойских толщ, зафиксирован образованием коры выветривания на архейских породах Курской ГЗО и несогласным залеганием палеопротерозойских толщ относительно архейских структур. В некоторых участках разрезы железорудных поясов отделены от архейского основания породами лебединской серии, сформированными в конце неоархея. Длительная тектоническая пауза от 2.9 до 2.6 млрд лет предшествовала накоплению осадочных пород и ультракалиевых кислых вулканитов лебединской серии [Mints et al., 2010, and references therein], что позволяет связывать их появление с инициальной стадией палеопротерозойского рифтинга архейского кратона. Соотношения лебединской серии с перекрывающей ее курской серией включают относительно краткий стратиграфический перерыв и отсутствие структурного несогласия [Polishchuk et al., 1970; Nozhkin, Krestin, 1984].

Курская серия, образующая нижнюю часть палеопротерозойского разреза, включает две свиты: нижнюю - стойленскую и верхнюю - коробковскую. Стойленская свита сложена в основании кварцевыми аренитами с линзами кварцевых конгломератов и гравелитов, ортокварцитами. Выше залегают метаалевролиты и метапелиты, филлитовые и углеродистые сланцы. Мощность свиты варьируется от нескольких метров в антиформных структурах, расположенных в промежутках между интенсивными магнитными аномалиями), до сотен метров в крупных синформах [Krestin, 


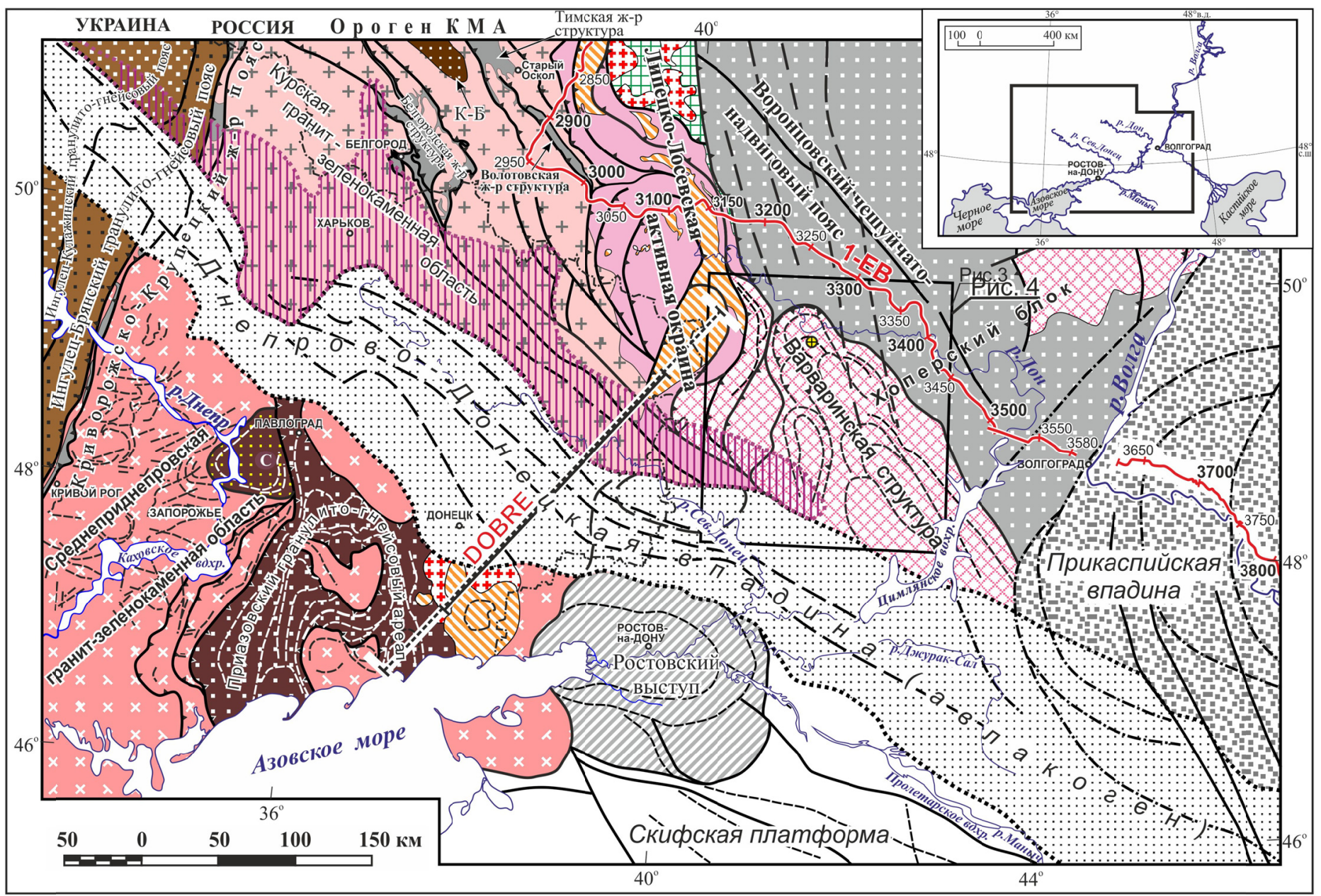

Рис. 2а. Геологическая карта юго-восточной части Восточно-Европейского кратона.

Fig. 2a. The geological map of the south-eastern segment of the East European craton.

1975; Plaksenko et al., 1980]. Коробковская свита (железисто-кремнисто-сланцевая формация) залегает на стойленской свите без каких-либо следов несогласия. В наиболее полных разрезах коробковская свита сложена чередующимися толщами железистых кварцитов и сланцев, общая мощность которых превышает один километр. С коробковской свитой связан ряд уникальных по запасам железорудных месторождений, сгруппированных преимущественно в пределах КрупецкоРыльского, Железногорско-Михайловского, Белгородского и Оскольского рудных полей. Между курской серией и перекрывающими породами оскольской серии наблюдаются как постепенные переходы, так и стратиграфическое несогласие. Вулканиты в составе оскольской серии образованы бимодальной ассоциацией рифтогенного типа: сочетанием высококалиевых липаритов с подчиненным количеством метамафитов (Михайловская структура) и высокотитанистых метатолеитов (Тим-Ястребовская структура) [Nozhkin, Krestin, 1984]. Мощность разрезов достигает нескольких километров. Оценки температур метаморфизма железорудных поясов варьируются от участка к участку в интервале от 420-500 до 580-620 ${ }^{\circ} \mathrm{C}$ при давлениях от 2-3 до 5 кбар [Savko, Polyakova, 2000; Savko, Kal'mutskaya, 2001; Savko et al., 2003; Savko, Poskryakova, 2003]. Относительно высокие температуры метаморфизма вулканогенно-осадочных пород на небольших или умеренных глубинах свидетельствуют о том, что температуры в подстилающей архейской коре должны были достигать уровня гранулитовой фации. Структурные особенности орогена КМА позволяют заключить, что тектоническое сжатие на коллизионном этапе имело субширотную ориентировку и сопровождалось сдвиго-надвиговыми дислокациями (транспрессией) вдоль диагональных разрывов северо-западного простирания. Широкое развитие чешуйчато-надвиговых дислокаций позволяет рассматривать район КМА в качестве структуры орогенного типа.

Существование бассейнов железонакопления можно приблизительно отнести к интервалу 2.5-2.05 млрд лет [Tugariniov et al., 1964; Shcherbak et al., 1989, 1992]. Наиболее интенсивные магматические процессы 


\section{УСЛОВНЫЕ ОБОЗНАЧЕНИЯ}

\section{ПАЛЕОПРОТЕРОЗОЙ}

Воронцовский чешуйчато-надвиговый пояс, 2.2-2.02 млрд лет

Воронцовский метатерригенный комплекс

Липецко-Лосевская активная окраина,

2.1-2.02 млрд лет

Сиениты и граносиениты Павловского и

Хлебодаровского комплексов, 2.08-2.05

млрд лет

ғжғғғ. Граниты и плагиограниты Усманского и +++++.. Анадольского комплексов, 2.10-2.09 млрд лет

且团 Лосевская серия: метавулканиты (амфиболиты) 2.10 млрд лет

Донская серия: тоналито-гнейсы (предположительно, 2.10 млрд лет)

Архейские комплексы пород, частично перекрытые палеопротерозойскими породами воронцовской серии (Ростовский выступ)

Гранулито-гнейсовые пояса (ГГП), 2.2-2.05 млрд лет

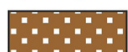

Ингулец-Кулажинский ГГП: преимущественно кондалиты

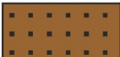

Ингулец-Брянский ГГП: гранат-гиперстеновые гнейсы, кондалиты, эвлизиты

Ороген Кривого Рога - Курской магнитной аномалии (KMA), от 2.6 до 2.04 млрд лет

Железорудные вулканогенно-осадочные пояса, 2.5-2.05 млрд лет

\section{АРХЕЙ}

Гранулито-гнейсовые ареалы (ГГА), 3.0-2.8 млрд лет

: : : : : К Курско-Бесединский (К-Б) и Приазовский : : : : : ГГА, 2.86-2.82 млрд лет

$::::::::$ Славгородский ГГА (C), 3.0 млрд лет;

Гранит-зеленокаменные области, 3.6-2.9 млрд лет

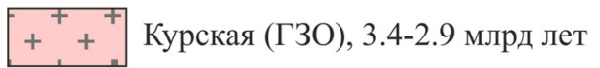

$x x^{x}$ Среднеприднепровская ГЗО и ее продолжение в Приазовье, 3.6-2.9 млрд лет

Хоперский блок (фундамент воронцовской серии)

\section{ФАНЕРОЗОЙ}

Прикаспийская впадина: осадочные

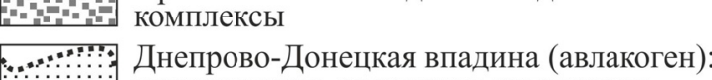
вулканогенно-осадочные комплексы

011[|[1]11] Измененные (разуплотненные) породы в обрамлении Днепрово-Донецкой впадины

\section{СТРУКТУРНЫЕ ОБОЗНАЧЕНИЯ}

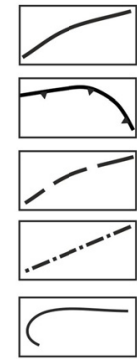
Тектонические нарушения, преимущественно сдвиги

Взбросо-надвиги

Тектонические нарушения, проведенные по границам магнитных и плотностных аномалий

Границы овальных синформ, определяющих строение Прикаспийской впадины

Геологические границы

Структурные линии, проведенные по

магнитным аномалиям: а - с указанием наклона по 3-мсрной модсли, б - с неизвестной ориентировкой

\section{ДОПОЛНИТЕЛЬНЫЕ ОБОЗНАЧЕНИЯ НА} ГЛУБИННЫХ РАЗРЕЗАХ

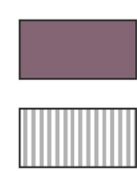

"Расслоенная нижняя кора" -

предположительно гранулит-базитовый комплекс ("зога рефлективити")

“Коро-мантийная смесь" (область с малопротяженными пакетами отражении, транслирующими в мантию структуры нижней коры)

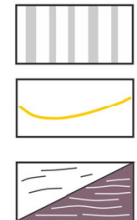

Мантия (акустически прозрачная область)

Границы стратиграфических подразделений в палеозойском разрезе Днепрово-Донецкой впадины

Сейсмические отражения

\section{ГЕОTPABEPCЫ}

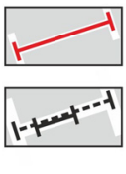

Геотраверс 1-EB

Профиль DOBRE: ГС3 - пунктир,

OГТ - сплошная линия

$\oplus$ Варваринская скважина

Рис. 2б. Таблица условных обозначений (соответствует рисункам 2-4 и 6-7).

Fig. 2б. The legend for Figures 2, 3, 4, 6, and 7.

рифтогенного типа отвечали началу ( 2.5 млрд лет) и концу ( 2.20-2.05 млрд лет) этого интервала. Наиболее интенсивные проявления магматизма отвечают интервалу 2.09-2.04 млрд лет [Shcherbak et al., 1992; Artemenko et al., 1992; Artemenko, 1995, 1997, 1998].

Восточно-Воронежский ороген включает ЛипецкоЛосевский вулканоплутонический и Воронцовский чешуйчато-надвиговый пояса, которые разделены Ло-
севско-Мамонским швом. Мощность зоны тектонитов, связанных с этим швом, достигает нескольких километров [Raskatov et al., 19176]. Особенности геологического строения, демонстрируемые геологическими картами BKM [Molotkov et al., 1999; Sarkisova, 2001], и результаты геологической интерпретации сейсмического образа коры по геотраверсу 1-EB [Mints et al., 2010] показывают, что породы Липецко-Лосевского 


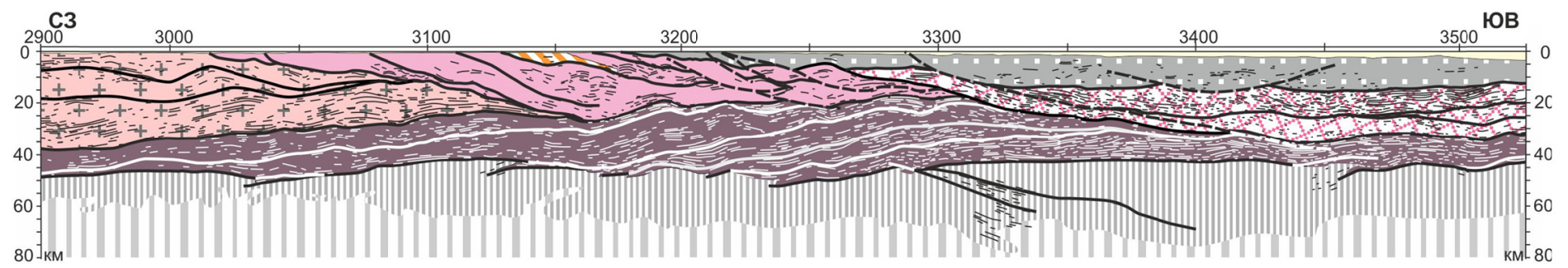

Рис. 3. Геологический разрез по геотраверсу 1-ЕВ в интервале 2900-3500 км (по [Mints et al., 2010], адаптировано к содержанию статьи). Условные обозначения - см. на рис. 2.

Fig. 3. The geological cross-section along geotraverse 1-EU for the segment from 2900 to $3500 \mathrm{~km}$ (according to [Mints et al., 2010], adapted for the article's content). See the legend in Fig. 2.

пояса размещены поверх Курской ГЗО. В свою очередь, основание палеопротерозойского разреза Воронцовского пояса образовано породами Хоперского блока.

Обширная область коры на востоке ВКМ, сложенная на уровне поверхности фундамента воронцовской серией, первоначально получила наименование Восточно-Воронежской или Бобровско-Воронцовской [Gorbunov et al., 1973]. Впоследствии эта структурная область обозначалась как Калач-Эртильская или Хоперская [Chernyshov et al., 1997]. Известны и другие названия: Калач-Эртильская, Восточно-Воронежская, Хоперская, Воронежско-Калачевская, Бобровско-Воронцовская структурно-формационные зоны. Несмотря на многолетнюю историю изучения воронцовской серии и пространственно связанных с ней рудоносных мафит-ультрамафитовых интрузивов, геодинамическая природа этой структуры оставалась во многом неясной. Были предложены различные варианты ее тектонической интерпретации: в качестве эпикратонного осадочного бассейна [Bocharov, Chernyshov, 1985], деформированного рифтогенного бассейна или преобразованной пассивной окраины [Rundquist et al., 1999], аккреционной призмы [Bush et al., 2000; Shchipansky et al., 2007]. В работе [Mints et al., 2010] мы вернулись к наименованию Хоперский блок (кратон), понимая под этим названием континентальную массу, образованную слабоизученной гранитогнейсовой (гранит-мигматитовой) ассоциацией пород предположительно архейского возраста, которая в современной структуре отделена от кратона Волго-Уралия позднепалеопротерозойским Северо-Воронежским, а от Курского кратона - среднепалеопротерозойским Восточно-Воронежским коллизионным орогеном. Непосредственным участием Хоперского блока в строении ВосточноВоронежского орогена определяется специальное внимание, которое мы уделяем его характеристике в данной статье.

Воронцовский чешуйчато-надвиговый пояс охватывает восточную половину Восточно-Воронежского орогена. В меридиональном направлении протяжен- ность пояса превышает 600 км при ширине более 200 км. Породы воронцовской серии развиты на площади около 100000 км². Материалы глубинного геологического картирования и анализ сейсмических образов коры по профилю 1-ЕВ в интервале 3300-3600 км (рис. 3) показывают, что воронцовская серия подстилается мощной корой предположительно архейского возраста, которую мы соотносим с кратко охарактеризованным выше блоком Хопер [Mints et al., 2010]. Фрагменты разрезов, которые по составу, уровню метаморфизма и возрасту коррелируются с воронцовской серией, известны к северо-востоку от ВКМ - в пределах Волго-Уральского кратона, где они подстилаются архейскими гранулито-гнейсовыми комплексами [Bogdanova, 1986; Mints et al., 2010 and references therein]. Эта особенность распространения воронцовской серии свидетельствует о единстве (совмещении) Сарматии и Волго-Уралии в середине палеопротерозоя. В конце палеопротерозоя активные процессы рифтообразования разделили эти континентальные области, которые вскоре были вновь объединены разместившимся между ними Северо-Воронежским орогеном.

Воронцовская серия представляет собой мощную толщу песчанико-сланцевых флишоидных отложений. Отмечены участки развития углисто-графитовых сланцев и графитовых гнейсов [Zaitsev et al., 1978]. Coгласно результатам детального петрографического и петрохимического исследования пород воронцовской серии, приведенным в диссертационной работе E.M. Гурвича [Gurvich, 1975], в составе обломочного материала значительную роль играют вулканомиктовые и туфогенные компоненты. В менее измененных разностях сохранились реликтовые структуры и рогульчатая форма кварцевых частиц. Значительная часть метапсаммитов и сланцев воронцовской серии отвечает по составу грауваккам. Спорадическое присутствие голубого кварца, первично-высокотемпературное происхождение которого подтверждается наблюдающимися в его зернах включениями тончайших иголочек рутила и высоким (до 0.03 \%) содержанием титана [Gurvich, 1975], свидетельствует о высокотем- 
пературном типе вулканических извержений. Мощность серии в разрезе по профилю 1-ЕВ достигает 15 км (рис. 3), что позволяет говорить о грандиозном объеме отложений. Объем осадков, сохранившихся в современной структуре, можно оценить величиной порядка 10-15 миллионов км³, что лишь на порядок меньше объема осадков, заполняющих Прикаспийскую впадину. Метаморфические преобразования воронцовской серии относятся к андалузит-силлиманитовой фациальной серии [Lebedev, 1972]. Характерна пространственная зональность типа термальных ореолов. В высокотемпературных зонах сланцы преобразуются в гнейсы с крупночешуйчатым биотитом, мусковитом, гранатом, силлиманитом, калишпатом и кордиеритом. В известково-силикатных породах появляются клиноцоизит, амфиболы, диопсид и гранат. Прогрессивный Р-T тренд характеризуется ростом температуры от 460 до $750{ }^{\circ} \mathrm{C}$ и давления от 2-3 до 5-6 кбар. Поскольку в современной структуре низко- и высокотемпературные ассоциации размещены на одном уровне, следует предполагать подъем высокотемпературных разностей [Savko, Gerasimov, 2002].

Верхняя возрастная граница осадконакопления зафиксирована возрастом ультрамафит-мафитовых ксенолитов в кварцевых диоритах Новомеловатского массива - 2.13 млрд лет [Kremenetsky et al., 2007]. Оценка возраста зонального метаморфизма по метаморфогенным цирконам из зоны биотит-силлиманитовых гнейсов составила 2.10 млрд лет [Bibikova et al., 2009]. Детальное геохронологическое исследование методом Th-U-Pb химического датирования (CHIME) метаморфических монацитов дало более молодые оценки в интервале 2.02-2.00 млрд лет [Savko et al., 2012], которые могут фиксировать повторный термальный импульс.

Воронцовский пояс включает многочисленные интрузивные тела, образованные рудоносными (Cu-Ni, $\mathrm{Pt}$ ) мафит-ультрамафитами и гранитоидами. Максимальная насыщенность интрузивными телами установлена в западной части пояса в полосе шириной 50130 км при протяженности до 400 км, непосредственно примыкающей к Лосевско-Мамонскому шву.

Мамонский комплекс включает дифференцированные массивы дунит-перидотит-габброноритовой формации [Chernyshov, 1996]. Как правило, это массивы небольших размеров и разнообразной морфологии: дугообразные и изометрично-овальные в плане, они образуют в разрезе крутопадающие пластообразные, трубообразные и факколитоподобные тела. Возраст комплекса - 2.08 млрд лет [Chernyshov et al., 1990]. В охарактеризованных ниже кварцевых диоритах Новомеловатского массива встречены ультрамафит-мафитовые ксенолиты (оливинсодержащие плагиовебстериты-меланогаббронориты-лейкогаббронориты). Возраст ксенолитов - 2.13 млрд лет [Kremenetsky et al., 2007], вероятно, отвечает началу формирования мамонского комплекса.
Еланский комплекс объединяет значительные по размеру (до $90 \mathrm{kм}^{2}$ в плане) лополитообразные дифференцированные массивы пироксенит-норит-диоритовой формации с возрастом 2.06 млрд лет [Chernyshov et al., 1990; Chernyshov, 1996]. Воронежской параметрической скважиной было вскрыто интрузивное тело, названное Новомеловатским массивом, которое образовано биотит-гиперстеновыми диорит-порфиритами, биотит-роговообманковыми кварцевыми диоритами и роговообманково-биотитовыми и биотитовыми гранодиоритами. Геохимические тренды дифференциации и закономерности распределения РЗЭ указывают на принадлежность этих пород к единой дифференцированной магматической серии. Становление Новомеловатского массива связано с узким временным интервалом 2.06-2.05 млрд лет [Kremenetsky et al., 2007]), что наряду с особенностями состава позволяет соотносить его с еланским комплексом.

Бобровский комплекс биотитовых и биотит-мусковитовых гранитов S-типа объединяет ряд мелких (до $5 \mathrm{kм}^{2}$ ) и средних (до $50 \mathrm{kм}^{2}$ ) интрузивов. Жильная фация представлена гранит-порфирами, аплитами и пегматитами. Возраст комплекса - 2.02 млрд лет [Bibikova et al., 2009]. Близкие по возрасту пироксенсодержащие высокотемпературные микроклиновые граниты вскрыты Терсинской скважиной, пройденной в северо-восточной части области, перекрытой породами воронцовской серии. Согласно данным бурения, в этой области также распространены метаморфические породы и гранитогнейсы, которые можно соотносить с Хоперским блоком, а также породы воронцовской серии. Возраст терсинских гранитов близок возрасту бобровского комплекса - 2.05-2.04 млрд лет [Bibikova et al., 2009].

Сведения о породах Хоперского блока до недавнего времени были ограничены результатами бурения в районах Саратовского и Волгоградского правобережья. В фундаменте Восточно-Европейской платформы выделены чередующиеся зоны северо-западного простирания. В пределах «Хоперской антиклинорной зоны» преобладают амфибол-биотиовые, гранат-амфибол-биотитовые плагиогнейсы, амфиболиты, плагиограниты и гранодиориты предположительно архейского возраста. Другие зоны сложены сланцами воронцовской серии и микроклиновыми турмалинсодержащими гранитами предположительно протерозойского возраста [Karpov et al., 1967]. В южной части Воронцовского пояса в тектоническом окне обнажаются архейские породы, слагающие Варваринский выступ [Belov, 1969; Granovsky, Zelenshchikov, 2008]. Предполагалось, что диаметр овального тектонического окна составляет 40 км по длинной оси [Kolosovskaya, 1992]. В дальнейшем, с учетом особенностей геофизических полей, область предполагаемого распространения архейских пород в южной части Хоперского блока была значительно расширена [Molotkov et al., 1999; Sarkisova, 2001]. Детальный анализ геофизических ма- 
териалов, недавно полученных в ЗАО «Аэрогеофизика», позволил значительно уточнить и расширить эти представления и, в частности, установить синформный характер архейской структуры, которая первоначально была названа «Чирской синформой». В предлагаемой статье мы сохраняем более раннее наименование структуры, повторяющее название Варваринского хутора, близ которого была пробурена скважина, вскрывшая породы фундамента (рис. 1, 2, 4).

В результате интерпретации гравитационных и магнитных карт, полученных в «Аэрогеофизике» в 2008-2011 гг., были построены 3-мерные петрофизические модели коры Варваринской структуры (на базе эффективных оценок плотности и намагниченности пород; методология моделирования реализована в пакете СИГМА-3D - Структурная Интерпретация Гравитационных и Магнитных Аномалий) [Babayants et al., 2003, 2004]). Наиболее информативные материалы представлены на рис. 4, 5. Контуры Варваринской структуры, замыкающейся в северо-западном направлении и расширяющейся к юго-востоку, равно как и контуры овальных образований в ее внутренней области, отчетливо читаются на картах аномального магнитного поля и его производных. Преобладание высокоплотных пород в северной части структуры демонстрируется картой поля силы тяжести и картой эффективной плотности. Кроме того, карты, представленные на рис. 4, свидетельствуют о значительных различиях в петрофизических характеристиках палеопротерозойских пород Донской ассоциации и Павловского комплекса, принадлежащих Липецко-Лосевской активной окраине, с одной стороны, и пород, образующих Варваринскую структуру - с другой. Первым отвечают более высокие значения магнитного поля и намагниченности и относительно более низкие значения поля силы тяжести и оценки эффективной плотности. Эти различия демонстрируются также и мелкомасштабными картами региональных физических полей (см., например, в [Mints et al., 2010]). Сопоставление продольного и поперечного сечений 3-мерной петроплотностной модели Варваринской структуры (рис. 5) демонстрирует ее синформное внутреннее строение, воздымание к северо-западу и погружение в противоположном направлении. Сечения петромагнитной модели оказались малоинформативными. Поперечный разрез магнитной модели в согласии с петроплотностным разрезом свидетельствует о перекрытии северо-восточного крыла структуры низкоплотными и низкомагнитными породами воронцовской серии.

Модельные петрофизические характеристики структуры в сочетании с данными, полученными при бурении Варваринской скважины, свидетельствуют, что в основании «разреза» значительную роль играют высокоплотные породы, в некоторых «слоях» отличающиеся высокой намагниченностью, которые можно сопоставить с метапироксенитами и амфиболовыми гнейсами, обнаруженными при бурении Варваринской скважины [Granovsky, Zelenshchikov, 2008]. Преобладающая по площади юго-восточная часть Варваринской структуры сложена породами умеренной плотности и намагниченности, предположительно плагиогнейсами и амфиболитами.

Липецко-Лосевский вулканоплутонический пояс располагается на восточной окраине Курского кратона (соответственно, к востоку от внутриконтинентального орогена KMA) и непосредственно граничит с Воронцовским поясом (см. рис. 1, 2). Лосевская серия один из главных компонентов этого пояса, образована метатолеитами (зеленые сланцы, актинолитовые амфиболиты, амфиболиты), метадацитами и метариолитами, а также метаморфизованными осадочно-вулканогенными породами. В качестве лосевской серии палеопротерозойского возраста эти метавулканиты были впервые выделены Ю.С. Зайцевым [Zaitsev, 1966]. Впоследствии на изданных картах ВКМ серия обозначалась как верхнеархейская, а в действующей стратиграфической схеме она отнесена к неразделенному верхнему архею - нижнему протерозою [Molotkov et al., 1999; Sarkisova, 2001].

Известны взаимоисключающие оценки формационной принадлежности метавулканитов, в частности отмечался полимодальный характер вулканизма с геохимическими особенностями, свойственными для островодужных систем [Gorbunov et al., 1973; Terent'ev, 2002; Shchipansky, Bogdanova, 1996]; с другой стороны, предлагалась возможность интерпретации лосевской серии в качестве бимодальной ассоциации, возникшей при рифтогенезе древней сиалической коры [Terent'ev, 2002]. По геохимическим характеристикам, полученным А.А. Щипанским с соавторами [Shchipansky et al., 2007], метавулканиты лосевской серии образуют бимодальную ассоциацию, формировавшуюся на активной окраине. Уровень метаморфизма повышается от фации зеленых сланцев в северной части пояса до верхов эпидот-амфиболитовой и низов амфиболитовой фации в его южной части [Zaitsev et al., 1978]. Оценки максимальных значений параметров метаморфизма достигают 500-600 ㄷ при давлении 5-6 кбар [Savko, Gerasimov, 2002]. Возраст лосевской серии непосредственно не установлен. Верхняя возрастная граница определяется возрастом гранитоидов Усманского комплекса, прорывающих лосевскую серию, - 2.10 млрд лет.

Интрузивные комплексы в пределах Липецко-Лосевского пояса представлены широким кругом близких по возрасту пород разного состава - от ультраосновного и основного до кислого. Пространственно и, по-видимому, генетически с метатолеитами лосевской серии связаны небольшие тела метаморфизованных ультраосновных и основных интрузивных пород. Крупные гранитоидные тела, сложенные кварцевыми диоритами, тоналитами, диоритами и плагиогранитами (трондьемитами), овальной формы от 10 до 40 км в поперечнике, сопровождаемые многочисленными 


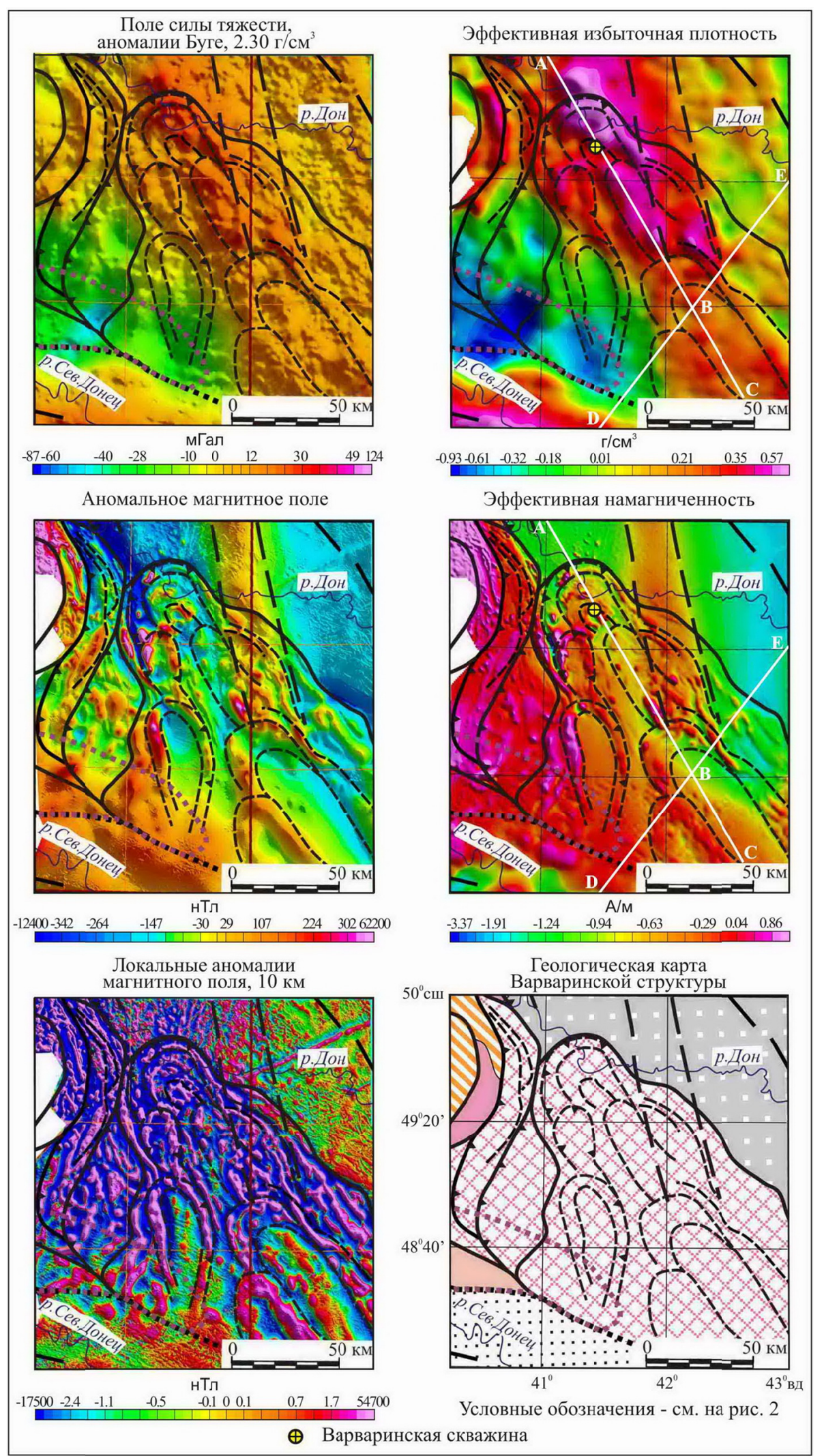

Рис. 4. Варваринская структура: карты физических полей и эффективных петрофизических параметров (по материалам ЗАО ГНПП «Аэрогеофизика»), геологическая карта.

Положение рисунка и условные обозначения к геологической карте - см. на рис. 2.

Fig. 4. The Varvarino structure: maps of geophysical fields and effective petrophysical parameters (according to data provided by Aerogeophysica Inc.), and a geological map.

See the location shown in the figure and the legend to the geological map in Fig. 2. 


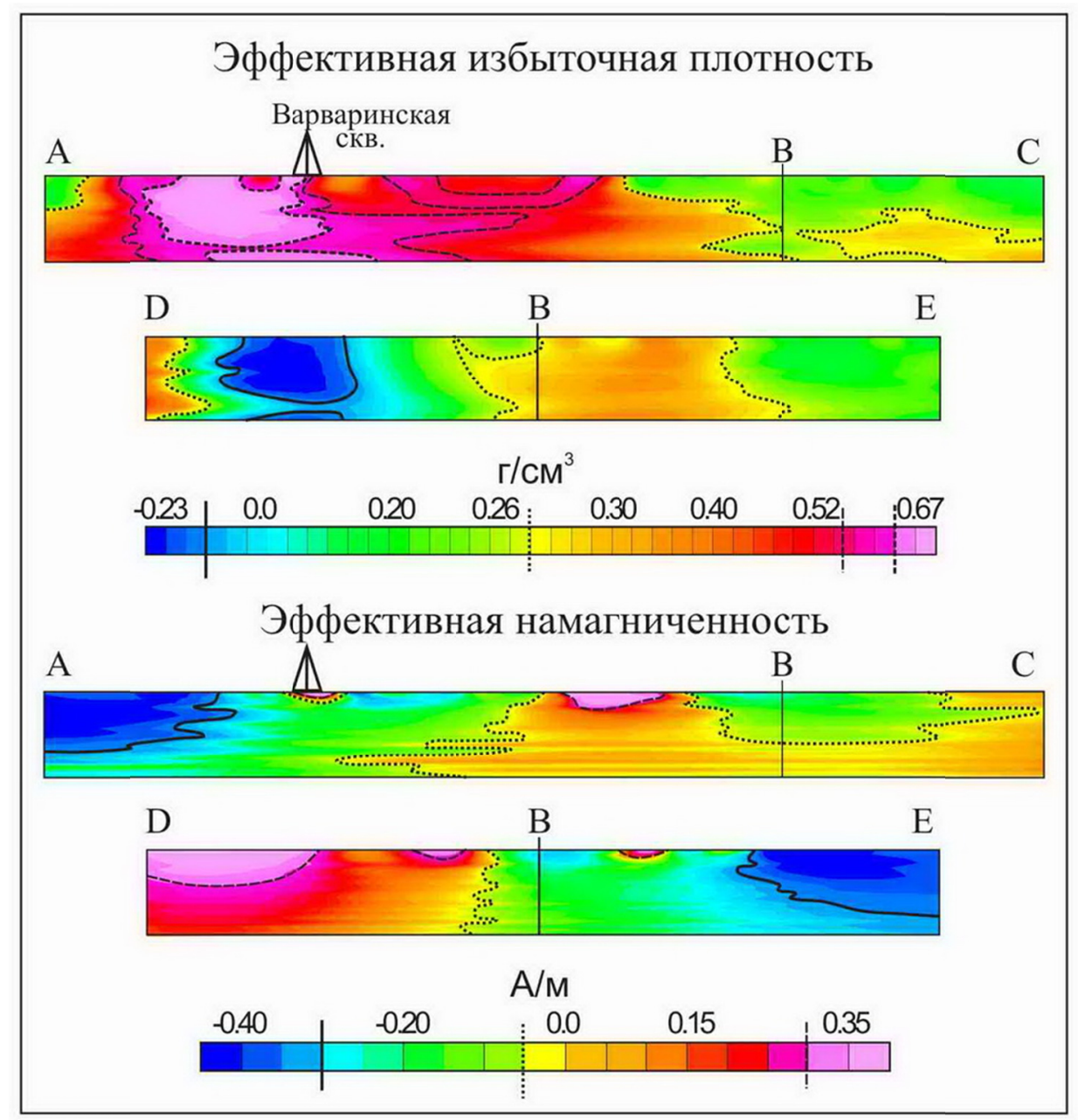

Рис. 5. Разрезы - вертикальные сечения 3-мерных моделей эффективных значений плотности и намагниченности горных пород в районе Варваринской структуры (по материалам ЗАО ГНПП «Аэрогеофизика»). Размещение разрезов - см. на рис. 4.

Fig. 5. Cross-sections - vertical profiles of 3D models of effective values of density and magnetization of rocks in the area of the Varvarino structure (according to data provided by Aerogeophysica Inc.). Locations of the cross-sections are shown in Fig. 4.

дайками, относят к усманскому комплексу. По петрогеохимическим и изотопно-геохимическим характеристикам [Shchipansky et al., 2007] трондьемиты усманского комплекса близки риолитам лосевской серии. Возраст усманского комплекса - 2.10 млрд лет [Bibikova et al., 2009]. Изотопный состав $\mathrm{Nd}$ в риолитах, отнесенный к 2.10 млрд лет (инициальные значения $\varepsilon \mathrm{Nd}$ варьируются в узком интервале от +1.3 до +2.4$)$, предполагает небольшое участие корового компонента, обогащенного легкими РЗЭ. Более высокие инициальные значения $\varepsilon N d$ (от +3.1 до +6.0), характеризующие усманские трондьемиты, указывают на ювенильный мантийный источник трондьемитовых магм.

Гранитоиды Павловского комплекса преимущественно распространены в южной половине ЛипецкоЛосевского пояса. Комплекс представлен массивами протяженностью до 150 км, сложенными преимущественно мигматитами и разгнейсованными субщелоч- ными роговообманково-биотитовыми граносиенитами, гранодиоритами, подчиненно сиенитами и гранитами. В поперечном сечении вдоль профиля 1-ЕВ (см. рис. 3) массивы Павловского комплекса представляют собой пластинообразные тела, залегающие субсогласно в структуре Липецко-Лосевского пояса. Павловские граносиениты несколько моложе усманских плагиогранитов, их возраст равен 2.08 млрд лет [Bibikova et al., 2009].

В пределах Приазовской провинции УЩ вероятными аналогами Павловского комплекса являются гиперстеновые и двупироксеновые кварцевые сиениты и граниты Хлебодаровского комплекса, близкие по минеральному составу чарнокитам, возраст которых составил 2.05 млрд лет [Yesipchuk et al., 1990], и граносиениты кальмиусского массива [Shcherbakov, 2005]. Возрастными аналогами усманского комплекса в пределах Приазовской провинции УЩ являются монаци- 
тоносные плагиомикроклиновые гранитоиды анадольского комплекса (см. рис. 2), датированные 2.09 млрд лет [Vasilchenko et al., 1992; Shcherbakov, 2005]. Однако по особенностям состава анадольские гранитоиды более близки породам павловского комплекса.

Известково-щелочные и субщелочные диоритогнейсы Донской ассоциации преобладают в южной половине Липецко-Лосевского пояса. Обычно предполагается, что эти породы имеют раннеархейский возраст [Molotkov et al., 1999; Sarkisova, 2001]. Однако, согласно данным А.А. Щипанского с соавторами, диоритогнейсы и размещенные среди них субщелочные гранитоиды павловского комплекса имеют очень близкие $\mathrm{Sm}-\mathrm{Nd}$ и $\mathrm{Rb}-\mathrm{Sr}$ изотопно-геохронологические характеристики, что указывает на взаимосвязанное формирование этих пород. По петро- и геохимическим характеристикам гнейсы Донской ассоциации и гранитоиды павловского комплекса сопоставимы с породами активных континентальных окраин фанерозоя, формировавшимися на субдукционном или раннеорогенном этапе тектонической эволюции [Shchipansky et al., 2007].

Интрузивная деятельность в пределах и в тылу Липецко-Лосевской активной окраины на удалении до нескольких десятков километров от Лосевско-Мамонского шва завершилась внедрением интрузий типично платформенного типа. Начало этот процесса отмечено формированием ольховского комплекса 2.05 млрд лет назад [Chernyshov et al., 1998]. Наибольшими размерами отличается концентрически-зональный Ольховский массив, давший название всему комплексу. Периферические части массива сложены габбро-норитами, центральная зона - монцонитами и монцогранитами. Незначительно более молодой возраст предполагается для щелочных пироксенитов, сиенитов и карбонатитов Дубравинского комплекса и гранитов-рапакиви олымского комплекса - около 2.0 млрд лет [Kryvdik et al., 1987; Bocharov, Frolov, 1993].

В Приазовской провинции УЩ интрузивные тела, в том числе массивы щелочных пород, относящиеся к этому этапу, пользуются более широким распространением. С.Г. Кривдик с соавторами [Kryvdik et al., 2009] соотносят массивы щелочных пород с двумя разновозрастными формациями: 1) щелочно-ультраосновной (2.1-2.0 млрд лет) и 2) габбро-сиенитовой (1.8-1.7 млрд лет). Представителем первой формации является черниговский комплекс щелочно-ультраосновных пород и карбонатитов. К вытянутому в меридиональном направлении на 20 км при ширине до 600 м черниговскому массиву приурочено Новополтавское редкометалльное месторождение (Nb, Тa, Р3Э, апатит) [Kalashnik, 2011, and references therein]. Оценки возраста Черниговского комплекса находятся в интервале от 2.10 млрд лет [Zagnitko, Lugovaya, 1989] до 1.921.91 млрд лет [Yatsenko et al., 2002]). Шире распространены массивы габбро-сиенитовой формации. Южнокальчикский комплекс объединяет субщелочные габ- бро, анортозиты (андезиниты), верлиты, габбросиениты, монцониты, сиениты, кварцевые сиениты, амфибол-биотитовые граниты и сиенит-пегматиты [Shcherbakov, 2005]. Южнокальчикский массив, давший название комплексу, имеет много сходных черт с анортозит-рапакивигранитными плутонами [Kryvdik et al., 2009]. К сиенитовому штоку в южной части Володаровского массива приурочено характерное для внутриплитной обстановки цирконий-редкоземельное месторождение [Marchenko, Strekozov, 1999]. Октябрьский комплекс образован габбро-пироксенитами, субщелочными основными и ультраосновными породами, щелочными и нефелиновыми сиенитами, мариуполитами. В дайковой серии Октябрьского массива участвуют жильные карбонатиты и/или карбонатитоподобные породы [Kryvdik et al., 2009]. К этому же типу относится Малотерсянский щелочной массив, размещенный в северной части Ореховско-Павлоградской зоны [Kalashnik, 2011]. Небольшие массивы каменномогильского комплекса образованы лейкократовыми биотитовыми и мусковит-биотитовыми гранитами. К Краснокутскому массиву приурочены литиеносные сподуменовые и петалитовые пегматиты. По разным оценкам возраст перечисленных интрузивных комплексов равен 1.80 млрд лет [Shcherbakov, 2005, and references therein]. В северной части Воронцовского пояса в виде крупных кольцеобразных интрузий (лополитов) распространены массивы новогольского комплекса, которые рассматриваются в качестве троктолит-габброноритовой трапповой формации [Chernyshov, 1994].

Таким образом, проявления внутриплатформенного магматизма, для которого обычно предполагается связь с эндогенной активностью плюмового типа, заключены в интервале от 2.0 до 1.8 млрд лет, хотя наиболее ранние интрузивы внедрялись уже около 2.05 млрд лет.

\section{3. ОБЪЕМНАЯ МОДЕЛЬ ГЛУБИННОГО СТРОЕНИЯ ВОСТОЧНО-ВОРОНЕЖСКОГО ОРОГЕНА}

Геотраверс 1-ЕВ пересекает структуры ВосточноВоронежского коллизионного орогена в интервале 2900-3500 км в субширотном - юго-восточном направлении. Приблизительно перпендикулярно ему в северо-восточном направлении ороген пересечен профилем DOBRE (см. рис. 2). Совмещение обоих сечений позволяет создать объемное представление о глубинном строении Восточно-Воронежского орогена.

\section{1. ГЕОТРАВЕРС 1-EB}

Сейсмический разрез архейской коры Курской гранит-зеленокаменной области по геотраверсу 1-ЕВ (см. рис. 3) в пределах ВКМ характеризуется значительной насыщенностью сейсмическими отражениями [Mints et al., 2010]. Уровень «отражательности» не обнаружива- 
ет зависимости от глубины. В отдельных участках наблюдается более или менее отчетливое чередование пологонаклонных пакетов, различающихся уровнем «отражательности». Благодаря этой особенности и, как правило, закономерной ориентировке отдельных отражений и интерференционных пакетов в целом, структурный рисунок коры распознается достаточно уверенно. Он характеризуется незакономерным чередованием частично «срезающих» друг друга куполовидных структурных форм. Структурные линии обычно выполаживаются к нижней границе «слоев», в некоторых случаях они отчетливо «срезаются» структурами подстилающей области коры. В свою очередь, «прозрачные» и «полупрозрачные» области имеют более или менее изометричные очертания и занимают секущее положение относительно структурного рисунка. В целом, особенности сейсмического образа коры позволяют с необходимой уверенностью трассировать границы отдельных коровых пластин. Раздел между отражающей нижней корой и «полупрозрачной» мантией прослеживается так же достаточно уверенно, демонстрируя сложное строение коро-мантийной границы. Нижняя часть разреза коры мощностью 3-10 км, расположенная непосредственно поверх этой границы, отличается весьма умеренной интенсивностью отражений. Мощность коры варьируется в интервале 4050 км. Начиная с 2950 км, то есть с места, где профиль 1-ЕВ, совершив поворот на $90^{\circ}$, поворачивает к востоку и далее следует вкрест простирания в направлении границы Липецко-Лосевского и Воронцовского поясов, мощность архейской коры постепенно сокращается вплоть до полного выклинивания на уровне пикета 3300 км (см. рис. 3).

Липецко-Лосевский пояс пересечен геотраверсом 1ЕВ в интервале 3010-3175 км. Нижняя граница пояса, начиная от выхода этой границы к поверхности фундамента, прослежена на глубину по рисунку отражений. Сейсмический образ, в принципе, подобен образу подстилающей «гранит-зеленокаменной» коры. В интервале 3150-3300 км картина отражений демонстрирует многочисленные антиформные складки, «набегающие» в западном направлении.

Строение коры Хоперского блока охарактеризовано сейсмическим образом в интервале от 3400 до 3580 км. Картина отражений разительно отличается от представленного выше образа архейской коры Курской ГЗО. В коре Хоперского блока в сечении профилем 1-ЕВ отчетлива субгоризонтальная расслоенность по уровню «отражательности». В разрезе коры выделяются четыре «слоя»: два относительно прозрачных с ограниченным числом закономерно ориентированных отражений и два других, насыщенных субпараллельными преимущественно субгоризонтальными отражениями.

Первый сверху прозрачный «слой» ограничен подошвой на глубине около 15 км и перекрыт платформенным осадочным чехлом. Ниже, в интервале глубин от 15 до 25 км, залегает интенсивно отражающий «слой» мощностью около 10 км. Рельеф поверхности, разделяющей эти слои, в некоторой степени смоделирован пологонаклонными разрывами, которые намечены ориентировкой и распределением редких отражений в пределах верхнего «слоя». В некоторых случаях пологонаклонные отражения пересекают рисунок расслоенности второго «слоя» и даже проникают в третий «слой», который подобно первому выделяется низкой насыщенностью отражениями - является акустически «полупрозрачным». Мощность этого «слоя» не превышает 10 км. Его волнистоизогнутая подошва (она же - кровля нижнего отражающего «слоя») располагается на глубине 32-35 км. Наконец, в нижней части коры расположен «слой», насыщенный многочисленными отражающими площадками («зона рефлективити») протяженностью до 10 км, формирующими типичный образ «расслоенной нижней коры». Подошва нижнего «слоя», то есть собственно коро-мантийная граница, прослеживается очень четко на глубине 43-45 км по смене пакетов нижнекоровых отражений акустически прозрачной мантийной областью. В целом, сейсмический образ коры в этом интервале напоминает кору Карельского кратона [Mints et al., 2009, 2010; Mints, 2011].

Вернемся к характеристике картины отражений на стыке двух типов глубинного разреза - в интервале приблизительно от 3000 до 3400 км. Три верхних «слоя», слагающих кору блока Хопер, воздымаются в западном направлении, надвигаясь на породы Донской ассоциации, чей структурный рисунок также демонстрирует складки, «набегающие» в западном направлении. Напротив, «расслоенная нижняя кора» блока Хопер погружается к западу, размещаясь в итоге под «гранит-зеленокаменной» корой Курского кратона (см. рис. 3). Соответственно, в интервале от 3350 до 3230 км граница коры и мантии погружается с 43 км до глубины 50-52 км.

Оценить достоверность геологической интерпретации сейсмического образа коры была призвана Воронежская параметрическая скважина, которая была пробурена в районе пикета 3205 км геотраверса 1-EВ в 2006-2007 гг. К сожалению, скважина была размещена между пикетами 3200 и 3205 км в 30 км восточнее Лосевско-Мамонского шва - «проверяемой» границы, пересечение которой ожидалось приблизительно на глубине 3 км, то есть на предельной глубине бурения. В результате бурения эта главная задача оказалась нерешенной: скважина не достигла подошвы воронцовской серии, но при ограниченной точности прогноза и в отсутствие необходимого резерва глубины полученный ответ не может считаться определенным.

Структурно-геологическая интерпретация разреза по профилю 1-EB. На разрезе определенно опознаются границы геологических комплексов, известных на поверхности фундамента по данным геологического картирования и интерпретации региональных 
геофизических материалов (см. рис. 2) [Mints et al., 2010]). В районе, пересеченном геотраверсом, Липецко-Лосевский пояс образован диорито- и гранодиорито-гнейсами Донской ассоциации, вмещающими силлообразные согласные и частично секущие тела граносиенитов павловского комплекса. Модельные плотности диорито-гнейсов и граносиенитов равны 2.702.75 г/см ${ }^{3}$. Структурный рисунок коры указывает на пространственную и структурную связь пород Донской ассоциации и павловских гранитоидов. В интервале 3015-3300 км породы этих двух комплексов совместно слагают линзовидный пакет тектонических пластин, надвинутых в западном направлении на породы Курской ГЗО (Курского кратона). Этот пакет с максимальной мощностью около 30 км достигает поверхности фундамента в интервале 3015-3175 км и выклинивается в восточном направлении в районе пикета 3300 км на глубине около 18 км (см. рис. 3). Подстилающий донские гнейсы Курский гранит-зеленокаменный комплекс в сечении геотраверсом 1-ЕВ имеет клиновидную форму, уменьшается в мощности в восточном направлении и полностью выклинивается к пикету 3150 км на глубине 25 км.

Куполовидные формы, характерные для сейсмического образа архейской коры Курской ГЗО, в принципе, согласуются с откартированной на поверхности фундамента геологической структурой, образованной незакономерно распределенными гранитогнейсовыми куполами и размещенными в межкупольных синформах осадочно-вулканогенными комплексами зеленокаменных поясов. Мощность гранит-зеленокаменного комплекса на разрезе составляет 35-40 км. Для нижней половины этого комплекса характерен более спокойный рисунок с полого изгибающимися структурными линиями, что в определенной степени сближает образ этой части разреза с образом «гранулитовой нижней коры». Модельные плотности гранит-зеленокаменного

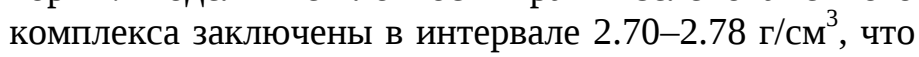
соответствует породам гранодиорит-тоналитового состава.

Четырехслойная кора в интервале 3390-3580 км целиком располагается в границах Воронцовского пояса и Хоперского блока. Верхний «слой» в интервале 3175-3570 км, очевидно, принадлежит терригенно-осадочному комплексу пород воронцовской серии с включениями мафит-ультрамафитовых и гранитных интрузивов. Модельная плотность этого комплекса составила 2.78 г $\mathrm{cm}^{3}$, в соответствии с известным набором и составом пород. «Слой» достигает максимальной мощности около 15 км в восточной части интервала. Состав трех коровых «слоев», залегающих ниже и не достигающих поверхности фундамента, может быть установлен лишь предположительно, с ориентацией на модельные оценки плотностей. Эти оценки составили: для второго по глубине слоя, насыщенного отражениями, - 2.85 г/см ${ }^{3}$; для третьего по глубине, умереннопрозрачного, «слоя» -2.78 г/см ${ }^{3}$; для самого нижнего,

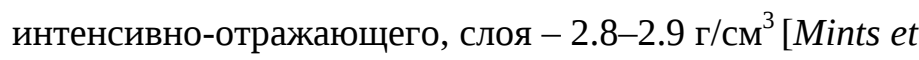
al., 2010]. Два слоя, насыщенные отражениями, получили относительно высокие оценки плотности, которые могут отвечать гнейсо-амфиболитовому комплексу или мигматизированным амфиболитовому или гранулитовому. С учетом размещения этого «слоя» под обширной областью континентальной коры по обе стороны от коллизионного шва уместно предположение о его формировании в результате андерплейтинга (подслаивания) мантийных расплавов. Для более определенного заключения необходимы независимые петрофизические данные, прежде всего оценки распределения скоростей.

В интервале 3000-4000 км картина отражений соответствует надвиго-поддвиговому ансамблю, образованному четырех-пятикратным повторением нижнекоровой пластины блока Хопер. Этот ансамбль можно рассматривать в качестве своеобразного аккреционного комплекса. Нижние пластины в интервале 3130 3200 км по профилю 1-ЕВ последовательно погружаются в мантию. Фрагменты «нижней коры» как бы растворяются в мантии и становятся компонентом «коро-мантийной смеси» - акустически прозрачной мантийной области, которую пересекают малопротяженные пакеты отражений, транслирующие в мантию структуры нижней коры.

\section{2. ПРОФИЛЬ DOBRE}

Профиль DOBRE (см. рис. 2) пересек восточную часть Приазовской провинции УЩ и юго-восточную часть ВКМ в северо-восточном направлении [Stovba et $a l ., 2006]$. Главной задачей этого профиля было исследование палеозойского Донецкого складчатого сооружения - сегмента Днепрово-Донецкой впадины. Особенности строения раннедокембрийского фундамента платформы в этой работе были охарактеризованы лишь схематически, поэтому для выяснения особенностей строения раннедокембрийской коры М.В. Минцем была дополнительно выполнена геологическая интерпретация картины сейсмических отражений в разрезе по профилю DOBRE (рис. 6) - с учетом результатов исследований по геотраверсу 1-EB (см. рис. 3) и геологических соотношений, представленных на карте фундамента (см. рис. 2).

Граница между областями коры, сложенными породами Курской ГЗО (в северной части профиля) и приазовского продолжения Среднеприднепровской ГЗО (в южной части профиля), контрастно выделяется, благодаря торцовому сочленению структурных рисунков. Курская ГЗО пододвинута под область коры Среднеприднепровской ГЗО. Акустически расслоенная «нижняя кора» прослеживается в основании разреза на всем протяжении профиля DOBRE как под Курской, так и под Среднеприднепровской ГЗО. По оценкам, полученным в результате интерпретации данных ГСЗ, плотность «нижней коры» по 


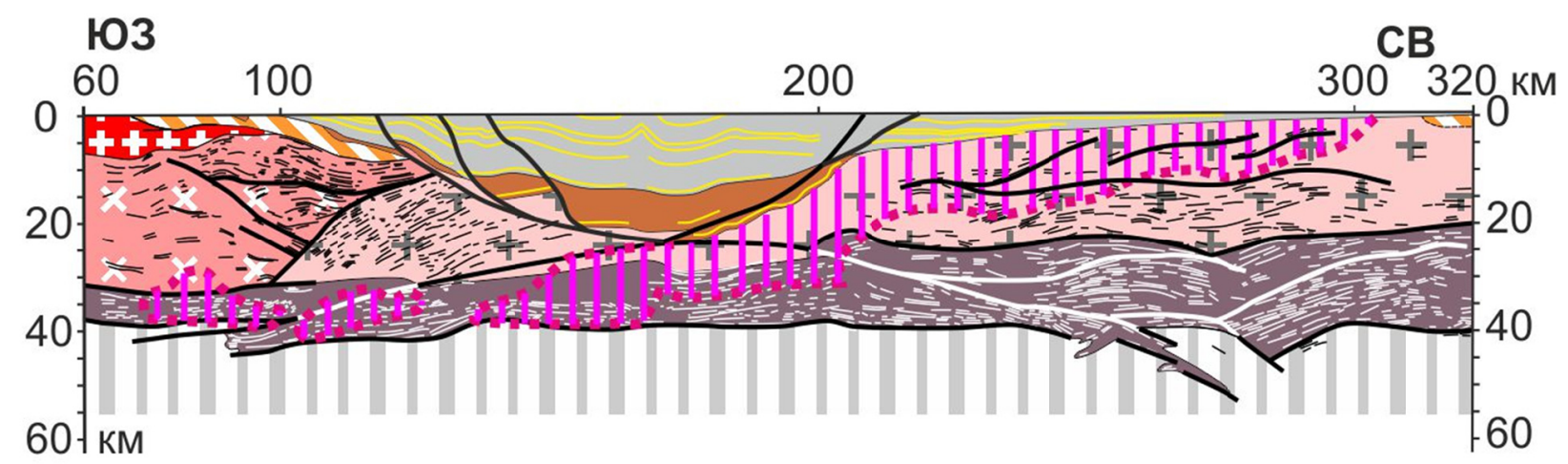

Рис. 6. Геологический разрез по профилю DOBRE.

Рисунок сейсмических отражений заимствован из [Stovba et al., 2006], геологическая интерпретация строения раннедокембрийской коры выполнена М.В. Минцем. Условные обозначения - см. на рис. 2.

Fig. 6. The geological cross-section along profile DOBRE.

Seismic reflections are taken from [Stovba et al., 2006]; the geological interpretation of the early Precambrian crust is done by M.V. Mints. See the legend in Fig. 2.

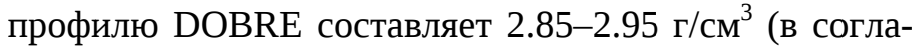
сии с расчетами по профилю 1-EB) и достигает 3.10 г/см ${ }^{3}$ под Днепрово-Донецкой впадиной [Stovba et $a l ., 2006]$. Реальность и вероятная природа предполагаемого возрастания мощности и плотности коры нижнекорового «слоя» заслуживают отдельного обсуждения, выходящего за рамки этой статьи.

Пространственное и структурное сопоставление разрезов вдоль профиля 1-ЕВ в интервале 31003400 км и вдоль профиля DOBRE позволяет достаточно уверенно коррелировать «нижнекоровый слой» в сечениях вдоль обоих профилей. Прослеживание этого «слоя» вплоть до южного конца профиля DOBRE согласуется с данными о распространении пород воронцовской серии в пределах Ростовского «выступа». Примечательно совпадение зоны резко пониженных значений поля силы тяжести, протягивающейся вдоль северной границы Днепрово-Донецкой впадины и выхода к поверхности фундамента акустически прозрачной области в коре, подстилающей северный борт впадины на разрезе по профилю DOBRE (рис. 2, 6).

Анализ сейсмического образа коры по профилю DOBRE позволяет сделать также ряд важных заключений о соотношениях архейских структурно-вещественных ассоциаций ВКМ и УЩ, которые мы представим в отдельной публикации.

\section{3. ОБЪЕМНАЯ МОДЕЛЬ ГЛУБИННОГО СТРОЕНИЯ}

Разработанное ранее объемное представление Восточно-Воронежского орогена [Mints et al., 2010] базировалось на пространственной корреляции структурно-вещественных комплексов на поверхности фундамента и их выражения в разрезе по геотраверсу 1-ЕВ. Геолого-геофизическое картирование Варваринской структуры и совмещение в рамках единой модели сечений по геотраверсу 1-EB и профилю DOBRE выявили ряд существенных дополнительных деталей строения Восточно-Воронежского орогена, которые демонстрируются объемной моделью (рис. 7). Воронцовский пояс в генеральном плане имеет синформное строение: породы предположительно архейского возраста, принадлежащие Хоперскому блоку, подверглись надвиганию в западном направлении при формировании Восточно-Воронежского орогена и в северо-восточном направлении в позднем палеопротерозое при формировании Северо-Воронежского орогена. В результате процессов надвигообразования и последовавшей эрозии эти породы достигают сегодняшней поверхности фундамента в северо-восточной части Воронцовского пояса - в районах Саратовского и Волгоградского Правобережья и в юго-западной части пояса в пределах Варваринской структуры.

Особенности нижнекорового «слоя», зафиксированные совместно профилями 1-EB и DOBRE, указывают на общность процесса андерплейтинга в пределах Хоперского блока и, по крайней мере, в сопредельной области Курского кратона. Области тектонического скучивания (торошения) нижнекорового «слоя» и формирование аккреционного надвиго-поддвигового структурного ансамбля на уровне «нижней коры» пространственно совмещены с надвиговым структурным ансамблем в верхней части, образованным тектоническими пластинами «средней коры» Хоперского блока, пород воронцовской серии и пород, слагающих Липецко-Лосевский пояс. Окраина Курского кратона образует тектонический клин, вдавленный в восточном направлении на 150 км. Структура коры в пограничной области между двумя континентальными образованиями - Курским кратоном и 


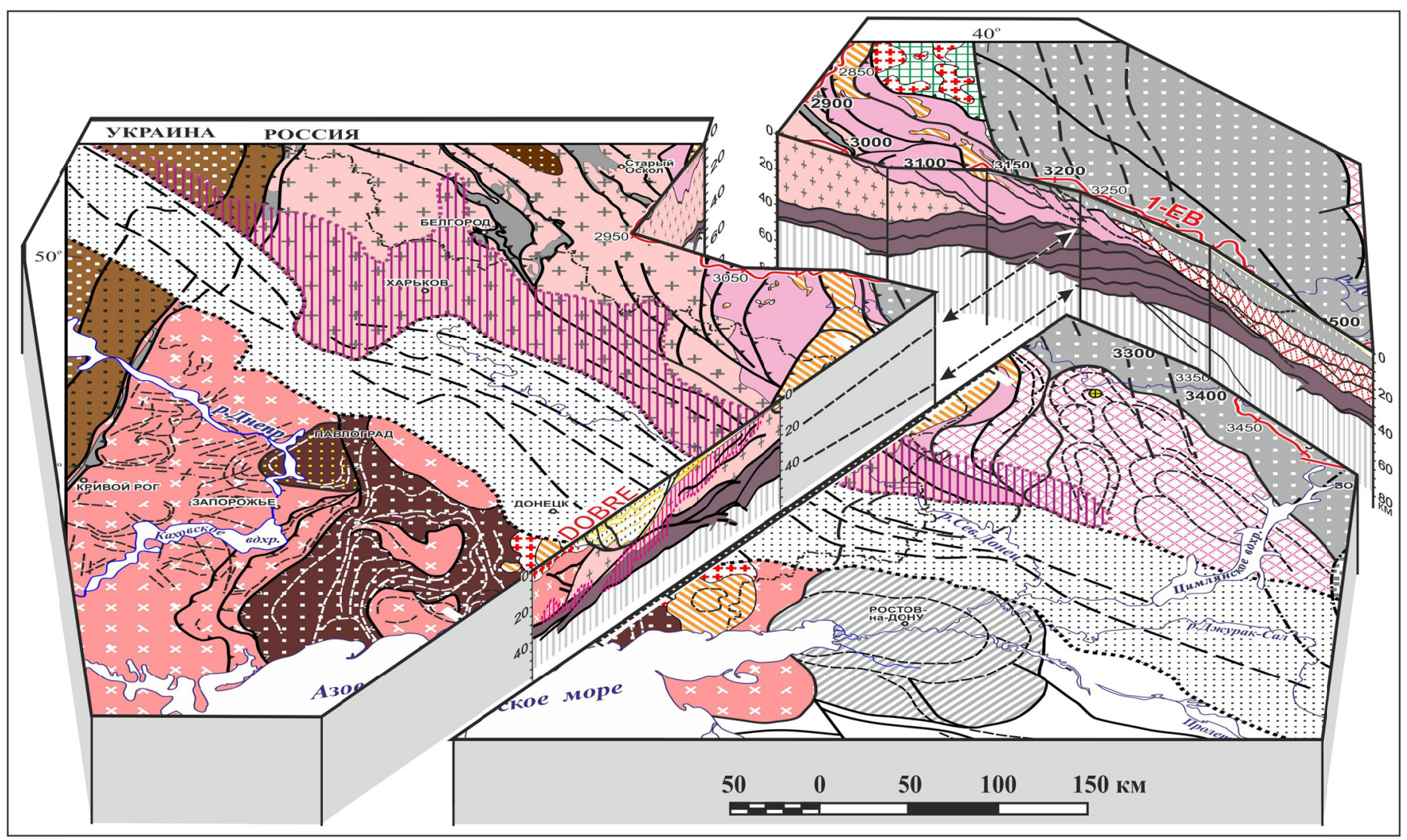

Рис. 7. Объемная модель глубинного строения Восточно-Воронежского орогена, объединяющая геологическую карту (рис. 2), разрезы по геотраверсу 1-EB (рис. 3) и профилю DOBRE (рис. 6). Условные обозначения - см. на рис. 2.

Fig. 7. The 3D model of the deep structure of the East Voronezh orogen which is based on the geological map (see Fig. 2) and the cross-sections along geotraverse 1-EU (see Fig. 3) and profile DOBRE (see Fig. 6). See the legend in Fig. 2.

Хоперским блоком - отвечает представлению о структурах типа «крокодил» или «пасть крокодила» [Meissner, 1989].

Совпадение зоны резко пониженных значений поля силы тяжести, протягивающейся вдоль северной границы Днепрово-Донецкой впадины (от -30 до -45 мГал) и выхода к поверхности фундамента акустически прозрачной области в коре, подстилающей северный борт впадины на разрезе по профилю DOBRE (рис. 2, 6), позволяет предполагать, что эта зона образована породами, которые были «разуплотнены» в процессе динамометаморфических преобразований в связи с возникновением Днепрово-Донецкой впадины.

\section{4. ОБСУЖДЕНИЕ: ЗАРОЖДЕНИЕ И} ГЕОДИНАМИЧЕСКАЯ ЭВОЛЮЦИЯ СРЕДНЕПАЛЕОПРОТЕРОЗОЙСКОГО БРЯНСК-КУРСК-ВОРОНЕЖСКОГО ОРОГЕНА

Наиболее яркие и значительные палеопротерозойские процессы в различных частях этой обширной территории связаны с кратким интервалом времени от 2.2 до 2.0 млрд лет. Более ранним стартом отличались события в пределах орогена КМА - около 2.6 млрд лет назад. Синхронизация событий в пределах орогенов второго порядка свидетельствует об их взаимосвязи и взаимообусловленности. Однако эти взаимосвязи не вполне очевидны и не находят достоверных аналогий в строении современных и молодых орогенов.

Ранее было показано, что повсеместно в геологической летописи вулканогенно-осадочные протолиты гранулито-гнейсовых комплексов формировались в обширных и протяженных внутриконтинентальных (частично - в задуговых) депрессиях рифтогенного типа и совместно с фундаментом этих депрессий подвергались высокотемпературному метаморфизму под воздействием мантийно-плюмовой активности. На заключительных стадиях эволюции в обстановке тектонического сжатия (внутриконтинентальной коллизии) гранулито-гнейсовые комплексы, сформированные за счет выполнения депрессий, выжимались на их борта, формируя синформные структуры гранулито-гнейсовых поясов [Mints et al., 2010; Mints, 2014]. Хотя Ингуло-Кулажинский гнейсовый и Ингулец-Брянский гра- 
нулито-гнейсовый пояса изучены относительно слабо, их принадлежность к рассматриваемому типу тектонических структур достаточно очевидна. Особенности разрезов железорудных поясов орогена КМА, а также Криворожского и Крупецко-Знаменского поясов также свидетельствуют об эпиконтинентальных условиях осадконакопления и вулканизма. Относительно высокий уровень метаморфизма железорудных вулканогенно-осадочных разрезов, заполнявших рифтогенные депрессии, свидетельствует о том, что температуры в средней и нижней коре в период формирования орогена КМА должны были соответствовать уровню гранулитовой фации.

Особенности разреза воронцовской серии также свидетельствуют об эпиконтинентальной природе Воронцовского бассейна осадконакопления. Объемное представление воронцовской серии, которая без значительных осложнений перекрывает мощную континентальную кору в полосе шириной около 400 км, противоречит интерпретации воронцовской серии в качестве «аккреционной призмы» [Shchipansky et al., 2007]. Выявленные особенности глубинного строения более всего напоминают структуру эпиконтинентального бассейна, краевая часть которого в процессе коллизии была перемещена на Липецко-Лосевскую активную окраину. Внутриконтинентальное происхождение рудоносных мафит-ультрамафитовых интрузивов, разместившихся среди пород воронцовской серии, также не вызывает сомнения [Bocharov, Chernyshov, 1985; Chernyshov et al., 1997; Rundquist et al., 1999; Mints et al., 2010].

Можно предположить, что четкая расслоенность коры, подстилающей воронцовскую серию, связана с процессами внутрикорового плавления и дифференциации вещества коры под воздействием интенсивного прогрева, зафиксированного термальными «куполами» в пределах воронцовской серии [Savko, Gerasimov, 2002], присутствием голубого кварца в метаосадках и высокотемпературном типе гранитоидов Бобровского и Терсинского (по [Bibikova et al., 2009]) комплексов. Расслоенность коры Хоперского блока, подстилающей воронцовскую серию, вероятно, определялась палеопротерозойскими тектонотермальными процессами. Овальные в плане синформные структуры, распознаваемые в верхней части коры Хоперского блока в пределах Варваринской структуры, возможно, фиксируют структуру погружений и образования впадин, которые затем объединились, образовав Воронцовский бассейн. Синформные структуры коры Хоперского блока морфологически сходны с гранулито-гнейсовыми овоидами и овалами Волго-Уральского кратона (см. в [Mints et al., 2010]).

Таким образом, среднепалеопротерозойские структурно-вещественные комплексы орогенов второго порядка формировались преимущественно во внутриконтинентальных обстановках. Частичный разрыв континентальной коры и формирование структуры океани- ческого типа предполагаются в единственном случае в осевой части Восточно-Воронежского орогена. В рамках предложенной структурно-геологической интерпретации разреза этот структурный образ связан с границей между двумя континентальными образованиями - Курским кратоном и Хоперским блоком, со сближением и столкновением (коллизией) которых 2.10-2.05 млрд лет назад связано формирование Липецко-Лосевского и Воронцовского поясов. Особенности строения области тектонического «скучивания» (торошения) нижнекорового «слоя» и формирование аккреционного надвиго-поддвигового структурного ансамбля на уровне «нижней коры» в непосредственной пространственной связи с размещением ЛосевскоМамонского шва и с учетом геохимических особенностей пород Липецко-Лосевского пояса позволяют интерпретировать эту область в качестве коллизионной сутуры на месте кратковременно раскрывавшегося океана. Тектонические структуры подобного типа характерны именно для подобных геодинамических ситуаций [Meissner, 1989; Teixell, 1998].

Минимальная приблизительная оценка латерального сокращения коры при формировании ВосточноВоронежского орогена, полученная на основании суммирования протяженности тектонических пластин «нижней коры», слагающих аккреционный ансамбль в интервале 3000-4000 км по геотраверсу 1-EВ, без учета не поддающейся оценке протяженности субдуцированной части коры, составляет 450 км. Оценить аналогичным образом латеральное сокращение верхней части коры можно лишь ориентировочно из-за разнообразия состава коровых пластин. Суммируя наблюдаемые в разрезе по геотраверсу 1-ЕВ относительные смещения к западу средней коры Хоперского блока и пород воронцовской серии, можно заключить, что минимальная оценка сокращения верхней части коры равна 200 км. Оперируя разностью этих величин в отсутствие данных о протяженности субдуцировавшей плиты, можно, в свою очередь, минимально-ориентировочно оценить ширину океанического бассейна, существовавшего в период 2.10-2.05 млрд лет между Курским кратоном и Хоперским блоком, несколькими сотнями километров.

В целом, эволюция Брянск-Курск-Воронежского орогена может быть охарактеризована следующей последовательностью геологических процессов, особенностями состава и времени формирования и преобразования главных структурно-вещественных комплексов (история зарождения и эволюции Восточно-Воронежского внутриконтинентального коллизионного орогена представлена на рис. 8).

1. Начало рифтогенеза архейского Курского кратона и заложение будущих железорудных поясов зафиксировано 2.60-2.53 млрд лет назад.

2. Период последовавших процессов осадконакопления и вулканизма в пределах «железорудных» прогибов, периодически сопровождавшийся интрузивной 


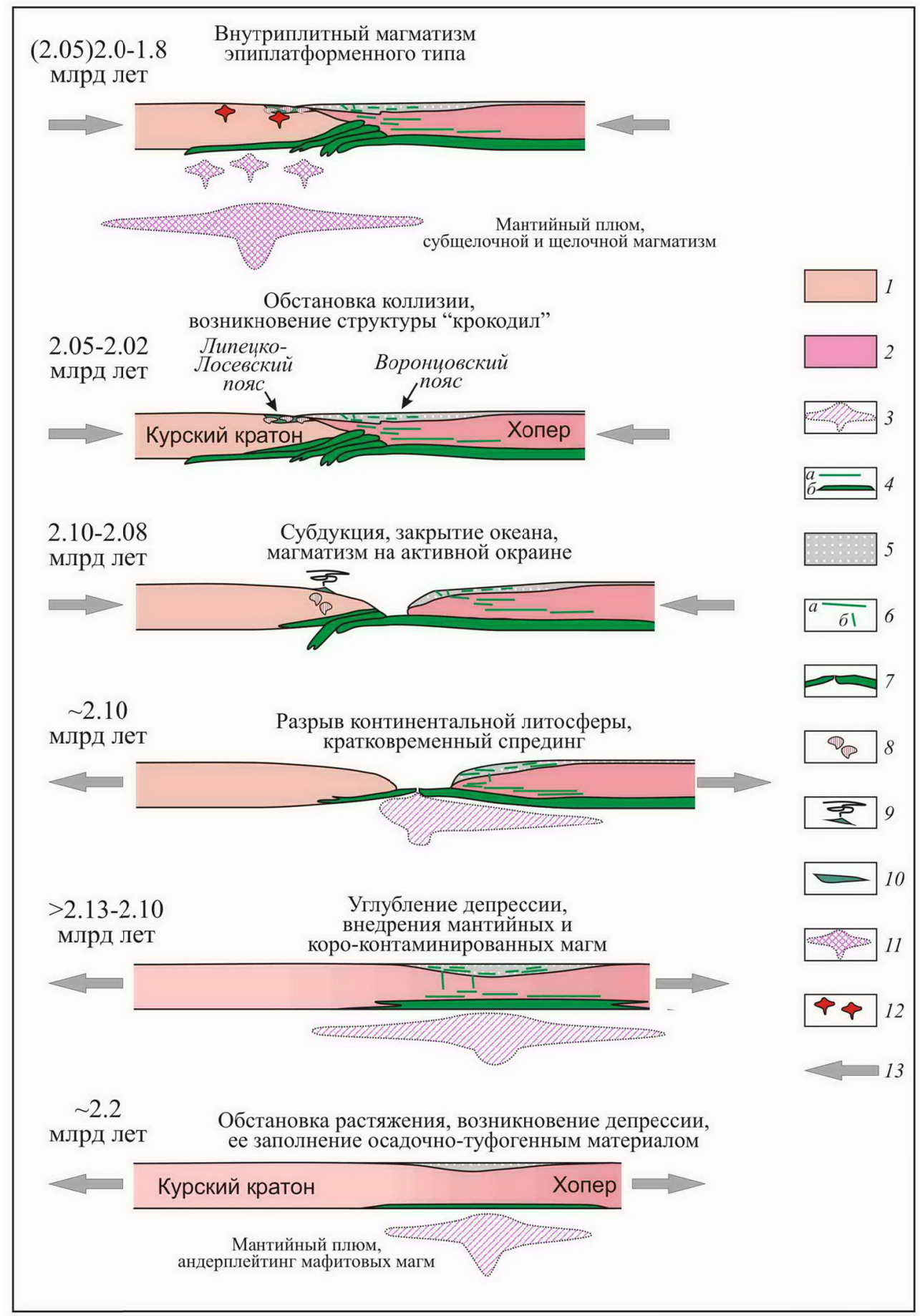

Рис. 8. Модель образования и эволюции Восточно-Воронежского внутриконтинентального коллизионного орогена.

1-2 - архейская кора: 1 - Курского кратона, 2 - блока Хопер; 3 - мантийный плюм, функционировавший от 2.2 до 2.1 млрд лет; 4 мафит-ультрамафитовые интрузивы, образованные в результате интерплейтинга (a) и андерплейтинга (б) мантийных магм; 5 - вулканогенно-осадочный комплекс воронцовской серии; 6 - субсогласные мафит-ультрамафитовые интрузивы (a) и дайки (б) Мамонского и Еланского комплексов; 7 - кора короткосуществовавшего океана; 8-10 - надсубдукционный магматизм: 8 - гранитоидные интрузивы Усманского, Павловского и Донского комплексов, 9 - вулканическая деятельность, 10 - лосевская осадочно-вулканогенная серия; 11 мантийный плюм, функционировавший от 2.0 до 1.8 млрд лет и его производные; 12 - щелочные интрузивы платформенного типа; 13 - направления тектонических напряжений.

Fig. 8. The model of the origin and evolution of the East Voronezh intra-continental collisional orogen.

1-2 - Archean crust: 1 - Kursk craton, 2 - Khoper block; 3 - mantle plume that was active in the period from 2.2 to 2.1 Ga; 4 - mafic-ultramafic intrusive bodies resulting from intraplating $(a)$ and underplating (б) of mantle magma; 5 - volcanosedimentary complex of the Vorontsovka series; 6 - sub-conordant mafic-ultramafic intrusive bodies (a) and dykes (6) of the Mamon and Elan complexes; 7 - crust of short-lived ocean; 8-10 suprasubduction magmatism: 8 - granitoid intrusive bodies of the Usman, Pavlovsk and Don complexes, 9 - volcanic activity, 10 - Losevka volcanosedimentary series; 11 - mantle plume active from $\sim 2.0$ to $\sim 1.8 \mathrm{Ga}$ and its derivatives; 12 - alkaline intrusive bodies of platform type; 13 - tectonic stress directions. 
активностью, приблизительно соответствует интервалу от 2.5 до 2.05 млрд лет. Наиболее интенсивные магматические процессы рифтогенного типа, свидетельствующие о повышенной проницаемости коры Курского кратона, отвечали началу ( 2.6-2.5 млрд лет) и концу ( 2.20-2.05 млрд лет) интервала. Относительно высокий уровень зонального метаморфизма вулканогенно-осадочных пород, заполнявших «железорудные» прогибы, свидетельствует о прогреве подстилающей архейской коры до уровня гранулитовой фации.

3. Формирование мощных эпиконтинентальных осадочных толщ с переменным участием вулканитов, начавшееся около 2.0 млрд лет, завершилось не позднее 2.13-2.10 млрд лет - времени, зафиксированного возрастом высокотемпературного метаморфизма пород Кулажинского и Воронцовского поясов и возрастом наиболее ранних интрузий Воронцовского пояса. Объемное представление воронцовской серии (см. рис. 7) более всего напоминает структуру эпиконтинентального осадочного бассейна.

4. Параметры метаморфизма достигали уровня гранулитовой фации (Кулажинский, Брянский, Воронцовский пояса). Возраст проявления пикового метаморфизма гранулитовой - высокотемпературной амфиболитовой фации оценен интервалом от 2.13 млрд лет (Кулажинский пояс) до 2.10 млрд лет (Воронцовский пояс). Четкая расслоенность коры Хоперского блока, подстилающей воронцовскую серию, могла быть связана с процессами внутрикорового плавления и дифференциации вещества коры.

5. Интрузивные процессы в пределах Воронцовского пояса развивались, в целом, синхронно с высокотемпературным метаморфизмом и продолжались после его завершения.

6. Надсубдукционный магматизм, результатом которого стало формирование Липецко-Лосевского вулканоплутонического комплекса, связан с интервалом 2.10-2.08 млрд лет, формирование активной окраины завершилось около 2.05 млрд лет назад. Кратковременность магматизма субдукционного типа и отсутствие информации о фрагментах океанической литосферы позволяют предполагать кратковременное и локализованное в пространстве существование океанической структуры.

7. Коллизионные деформации включали взбросонадвиговые дислокации и складкообразование в железорудных поясах, сопровождавшиеся опрокидыванием к западу и юго-западу взбросо-надвиговых структур и складок. По-видимому, к этому же времени относится выдавливание и преобразование в тектонические покровы метаморфизованного вулканогенно-осадочного выполнения Кулажинского, Брянского и Воронцовского бассейнов. Тектоническое сжатие имело субширотную ориентировку и сопровождалось сдвиго-надвиговыми дислокациями (транспрессией) вдоль диагональных разрывов северо-западного простирания. Непосредственной реакцией на тектоническое утолщение коры стали процессы реоморфизма и формирование купольных структур (реоморфических гранитогнейсовых и гранит-мигматитовых куполов), деформирующих покровно-складчатые ансамбли железорудных поясов КМА.

8. Тектонотермальная активность коллизионного и постколлизионного этапов ярко проявилась в размещении массивов щелочных пород щелочно-ультраосновной (2.1-2.0 млрд лет) и габбро-сиенитовой (1.81.7 млрд лет) формаций, сосредоточенных в пределах и в тылу Липецко-Лосевского пояса. Магматизм сопровождался метаморфическими преобразованиями пород, зафиксированными возрастом метаморфогенных монацитов (2.02-2.00 млрд лет) в породах воронцовской серии.

9. Как и в случае неоархейских и позднепалеопротерозойских внутриконтинентальных овальных орогенов (Карело-Беломорского, Волго-Уральского и Лапландско-Среднерусско-Южноприбалтийского), охарактеризованных М.В. Минцем с соавторами [Mints et al., 2010], формирование БКВО связано с тектонотермальной активностью мантийно-плюмового типа. Однако в отличие от перечисленных орогенов БКВО образован латеральной последовательностью орогенов второго порядка, характеризующихся линейной морфологией. Для выяснения причин этих различий требуются дальнейшие исследования, прежде всего исследование глубинного строения региона.

\section{5. ЗАКЛЮЧЕНИЕ}

В заключение суммируем главные особенности строения и палеопротерозойской эволюции БрянскКурск-Воронежского орогена:

1) формирование значительных по латеральным размерам и мощности вулканогенно-осадочных толщ, заполнявших обширные эпиконтинентальные бассейны рифтогенного характера, преобладание эпиконтинентальных условий магматизма;

2) кратковременность и пространственная ограниченность проявления процессов корообразования, связанного с субдукцией океанической литосферы, отсутствие фрагментов этой литосферы;

3) свидетельства интенсивного прогрева континентальной коры, в результате которого высокотемпературному метаморфизму вплоть до гранулитовой фации подверглись палеопротерозойские вулканогенно-осадочные толщи практически немедленно после завершения осадконакопления (очевидно, совместно с породами архейского основания);

4) синхронность главных тектономагматических событий;

5) коллизионный тип тектонических структур как в пределах Брянск-Курск-Воронежского орогена в целом, так и в пределах составляющих его орогенов второго порядка. 
Перечисленные выше характеристики трудно или невозможно объяснить в рамках геодинамической модели формирования аккреционных орогенов кордильерского типа. Более привлекательной представляется модель, предполагающая примат внутриконтинентальных геодинамических процессов и механизмов. Мафит-ультрамафитовый магматизм и проявление интенсивного прогрева коры - вплоть до уровня гранулитовой фации - указывают на особую роль, которую играли в зарождении и эволюции Брянск-Курск-Воронежского орогена процессы плюмового типа, обеспечивавшие притоки мантийного тепла и ювенильного вещества.

Геологическую историю, завершившуюся созиданием Брянск-Курск-Воронежского орогена, можно в главных чертах охарактеризовать закономерной последовательностью тектонотермальных событий. Начало этой последовательности зафиксировано рифтогенным растяжением коры 2.6-2.5 млрд лет и повторно 2.2-2.1 млрд лет назад. Их результатом стало возникновение обширных депрессий, быстро заполнявшихся вулканогенно-осадочными толщами (включая железисто-кремнистые осадки). Эти толщи вслед за накоплением оказывались в условиях высокотемпературного (до гранулитовой фации) метаморфизма. Надсубдукционный магматизм, результатом которого стало формирование Липецко-Лосевского вулканоплутонического комплекса, связан с интервалом 2.102.08 млрд лет, формирование активной окраины завершилось около 2.05 млрд лет назад. Кратковременность магматизма субдукционного типа и отсутствие информации о фрагментах океанической литосферы свидетельствуют о кратковременном и локализованном в пространстве существовании океанической структуры. Тектонотермальная активность коллизионного и постколлизионного этапов проявилась в размещении массивов щелочных пород щелочно-ультраосновной (2.1-2.0 млрд лет) и габбро-сиенитовой (1.81.7 млрд лет) формаций.

Таким образом, наиболее активная фаза тектонической эволюции охватила интервал приблизительно от 2.2 до 2.0 млрд лет продолжительностью около 200 миллионов лет. Этот интервал времени практически совпадает с активной стадией растяжения, осадконакопления и высокотемпературного метаморфизма в северной части BEK [Mints et al., 2010; Mints, 2014]. Однако в пределах Брянск-Курск-Воронежского орогена эти процессы быстро сменились событиями коллизионного типа. Вероятно, эту особенность следует связывать с ограниченным масштабом эндогенных событий мантийно-плюмового типа в пределах Сарматии, определившим скромные размеры и слабо проявленную структурную зональность внутриконтинентального Брянск-Курск-Воронежского орогена.

\section{6. БЛАГОДАРНОСТИ}

Работа поддержана РФФИ: проект № 11-05-00492. Авторы благодарны руководству ЗАО ГНПП «Аэрогеофизика» за возможность использования региональных геофизических материалов.

\section{7. ЛИТЕРАTУРA / REFERENCES}

Artemenko G.V., 1995. Geological correlation of volcanism and granitoid magmatism of the southeastern Ukrainian Shield and the Kursk magnetic anomaly. Geokhimiya i Rudoobrazovanie (Geochemistry and Ore Formation) 21, 129-142 (in Russian) [Артеменко Г.В. Геохронологическая корреляция вулканизма и гранитоидного магматизма юго-восточной части Украинского щита и Курской магнитной аномалии // Геохимия и рудообразование. 1995. Вып. 21. С. 129-142].

Artemenko G.V., 1997. Geological correlation of granitoids in the Voronezh Crystalline Massif and the Ukrainian Shield. Mineralogichesky Zhurnal (Mineralogical Journal) 19 (2), 79-88 (in Russian) [Артеменко Г.В. Геохронологическая корреляция гранитоидов Воронежского кристаллического массива и Украинского щита // Минералогический журнал. 1997. Т. 19. № 2. С. 79-88].

Artemenko G.V., 1998. Geochronology of the Middle Dnieper, Azov, and Kursk Granie-Greenstone Domains. DSc Thesis, Institute of Geochemistry, Mineralogy, and Ore Formation, National Academy of Sciences of Ukraine, Kiev, 31 p. (in Russian) [Артеменко Г.В. Геохронология Среднеприднепровской, Приазовской и Курской гранит-зеленокаменных областей: Автореф. дис. ... д.г.-м.н. Киев: Институт геохимии, минералогии и рудообразования НАН Украины, 1998. 31 с.].

Artemenko G.V., Bartnitsky E.N., Myasnyankin V.I., 1992. U-Pb age of igneous rocks in the Oriol-Tim Granite-Greenstone Domain of VCM. Doklady AN Ukraini (Transactions of the Ukraine Earth Sciences) 7, 113-117 (in Russian) [Артеменко Г.В., Бартницкий Е.Н., Мяснянкин В.И. Уран-свинцовый возраст магматических пород Орловско-Тимской зеленокаменной структуры ВКМ // Доклады АН Украины. 1992. № 7. С. 113-117].

Babayants P.S., Blokh Yu.I., Trusov A.A., 2003. Investigation of the crystalline basement of the platform areas based on magnetic and gravity data. Geofizika (Geophysics) 6, 55-58 (in Russian) [Бабаянц П.С., Блох Ю.И., Трусов А.А. Изучение строения кристаллического основания платформенных областей по данным магниторазведки и гравиразведки // Геофизика. 2003. № 6. С. 55-58].

Babayants P.S., Blokh Yu.I., Trusov A.A., 2004. The possibilities of a structural-material mapping based on the gravity and magnetic data in the software package SIGMA-3D. Geofisitshesky Vestnik (Geophysical Bulletin) 3, 11-15 (in Russian) 
[Бабаянц П.С., Блох Ю.И., Трусов А.А. Возможности структурно-вещественного картирования по данным магниторазведки и гравиразведки в пакете программ СИГМА-3D // Геофизический вестник. 2004. № 3. С. 11-15].

Belov F.A. (Ed.), 1969. Geologiya SSSR, Rostovskaya, Volgogradskaya, Astrakhanskaya Oblasti, Kalmitskaya ASSR. Geologicheskoe Opisanie (Geology of the USSR, Rostov, Volgograd, Astrakhan regions, Kalmyk Republic. Geological description). Nedra, Moscow, 666 p. (in Russian) [Белов Ф.А. (Ред.) Геология СССР. T. XLVI. Ростовская, Волгоградская, Астраханская области, Калмыцкая АССР. Геологическое описание. М.: Недра, 1969. 666 с.].

Bibikova E.V., Bogdanova S.V., Postnikov A.V., Popova L.P., Kirnozova T.I., Fugzan M.M., Glushchenko V.V., 2009. Sarmatia-Volgo-Uralia junction zone: Isotopic-geochronologic characteristic of supracrustal rocks and granitoids. Stratigraphy and Geological Correlation 17 (6), 561-573. http://dx.doi.org/10.1134/S086959380906001X.

Bocharov V.L., Chernyshov N.M., 1985. Early Precambrian endogenic regimes of the Voronezh Crystalline Massif. In: Endogenic regimes of the Earth's crust formation and ore deposition in Early Precambrian. Nauka, Leningrad, p. 192-205 (in Russian) [Бочаров В.Л., Чернышов Н.М. Эндогенные режимы раннего докембрия Воронежского кристаллического массива // Эндогенные режимы формирования земной коры и рудообразования в раннем докембрии. Л.: Наука, 1985. С. 192-205].

Bocharov V.L., Frolov S.M., 1993. Apatite-Bearing Carbonatites of KMA. Voronezh State University, Petrovsky Square Publ., Voronezh, 123 p. (in Russian) [Бочаров В.Л., Фролов С.М. Апатитоносные карбонатиты КМА. Воронеж: ВГУ, МП «Петровский сквер», 1993. 123 с.].

Bogdanova S.V., 1986. The Earth's Crust of the Russian Platform in the Early Precambrian. Transactions of the Geological Institute of the USSR Academy of Sciences, Vol. 408. Nauka, Moscow, 224 p. (in Russian) [Богданова С.В. Земная кора Русской плиты в раннем докембрии (на примере Волго-Уральского сегмента). М.: Наука, 1986. 224 с. (Труды ГИН АН СССР, вып. 408)].

Bogdanova S., Gorbatschev R., Garetsky R.G., 2005. EUROPE / East European Craton. In: Encyclopedia of Geology. Vol. 2. Elsevier, p. 34-49.

Bush W.A., Yermakov Yu.N., Uimanova L.N., 2000. A Geodynamic evolution model for the Late Archean-Early Proterozoic structures in the Voronezh Crystalline Massif. Geotectonics 34 (4), 267-276.

Cawood P.A., Kröner A., Collins W.J., Kusky T.M., Mooney W.D. Windley B.F., 2009. Accretionary orogens through Earth history. In: Cawood P.A., Kröner A. (Eds.). Earth accretionary systems in Space and Time. Geological Society London Special Publication 318, p. 1-36. http://dx.doi.org/10.1144/SP318.1.

Chernyshov N.M., 1994. Formation-genetic types of platina-metal ore-localities in Voronezh crystalline massif. In: Platinum of Russia. Problems of development of the mineral resource base of the platinum metals. Geoinformmark, Moscow, p. 85-103 (in Russian) [Чернышов Н.M. Формационно-генетические типы платинаметальных проявлений Воронежского кристаллического массива // Платина России. Проблемы развития минерально-сырьевой базы платиновых металлов. М.: АО «Геоинформмарк», 1994. С. 85-103].

Chernyshov N.M., 1996. Early Precambrian metallogeny of the Voronezh Crystalline Massif. Vestnik Voronezhskogo Universiteta. Geologiya (Voronezh University Bulletin. Geology) (1), 5-20 (in Russian) [Чернышов Н.М. Металлогения раннего докембрия Воронежского кристаллического массива // Вестник Воронежского Университета. Геология. 1996. № 1. C. 5-20].

Chernyshov N.M., Bayanova T.B., Levkovich N.V., Ryborak M.V., 1998. The age of rocks pertaining to the early phase of the Ol'khovy gabbronorite-quartz monzonite-granite ring complex in the Voronezh crystalline massif. Doklady Earth Sciences 359A (3), 444-446.

Chernyshov N.M., Nenakhov V.M., Lebedev I.P., Strik Yu.N., 1997. A model of geodynamic history of the Voronezh massif in the Early Precambrian. Geotectonics 31 (3), 186-194.

Chernyshov N.M., Ponomarenko A.N., Bartnitsky E.N., 1990. New data on age of Ni-bearing differentiated plutons in the Voronezh Crystalline Massif. Doklady AN UkrSSR (Transactions of the USSR Academy of Sciences), Series B (6), 11-19 (in Russian) [Чернышов Н.M., Пономаренко А.Н., Бартницкий Е.Н. Новые данные о возрасте никеленосных дифференцированных плутонов Воронежского кристаллического массива // Доклады АН УССР. 1990. Сер. Б. № 6. C. 11-19].

Claesson S., Bogdanova S.V., Bibikova E.V., Gorbatschev R., 2001. Isotopic evidence for Palaeoproterozoic accretion in the basement of the East European Craton. Tectonophysics 339 (1-2), 1-18. http://dx.doi.org/10.1016/S0040-1951(01) 00031-2.

Gorbunov G.I., Raskatov G.I., Zaitsev Yu.S., Chernyshov N.M., 1973. Principal features of Precambrian tectonics and geological history of the Voronezh Crystalline Massif. In: Tectonics of basement of ancient platforms. Nauka, Moscow, p. 4449 (in Russian) [Горбунов Г.И., Раскатов Г.И., Зайцев Ю.С., Чернышов Н.М. Основные черты тектоники и истории геологического развития докембрия Воронежского кристаллического массива // Тектоника фундамента древних платформ. М.: Наука, 1973. С. 44-49].

Granovsky A.G., Zelenshchikov G.V., 2008. Comparative analysis of the Precambrian structures in southern East European Platform (Rostov region). In: Connections of the surface and deep crustal structures. Transactions of the XIV International Conference. Part 1. Karelian Scientific Center, Russian Academy of Sciences, Petrozavodsk, p. 156-159 (in Russian) [Грановский А.Г., Зеленщиков Г.В. Сравнительный анализ докембрийских структур южной окраины Восточно-Европейской платформы (территория Ростовской области) // Связь поверхностных структур земной коры с глубинными. Материалы Четырнадцатой международной конференции. Ч. 1. Петрозаводск, Карел. НЦ РАН, 2008. C. 156-159]. 
Gurvich E.M., 1975. Petrography and Genesis of the Lower Proterozoic Rocks of the Voronezh Crystalline Massif and Volgograd Region: PhD Thesis. Moscow Institute of Petroleum Chemistry and Gas Industry, Moscow, 244 p. (in Russian) [Гурвич E.M. Петрография и вопросы генезиса нижнепротерозойских отложений Воронежского кристаллического массива и Волгоградского Поволжья: Дис. ... канд. геол.-мин. наук. М.: МИНХ и ГП, 1975. 244 с.].

Kalashnik A.A., 2011. Geological and structural features of endogenous uranium mineralization in the western Peri-Azov area and Orekhov-Pavlograd mineragenous zone of the Ukrainian Shield. Article 1. Geological and structural connection of uranium ore objects with fault structures, alkaline massifs and carbonatites in the study area. Collected Works of UkrDGRI (2), 56-72 (in Russian) [Калашник А.А. Геолого-структурные особенности проявления эндогенного уранового оруденения в Западном Приазовье и Орехово-Павлоградской минерагенической зоне Украинского щита. Статья 1. Геолого-структурная связь урановорудных объектов с разломными структурами, массивами щелочных пород и карбонатитов в районе исследований // Збірник наукових праць УкрДГРІ. 2011. № 2. С. 56-72].

Karpov P.A., Chugunov N.A., Voronkov A.V., Dobrokvashin I.A., Prokofiev N.A., 1967. Composition and physical properties of the basement rocks and small intrusions of Paleoproterozoic age of the Volgograd region. Proceedings of Volgograd Research Institute of Petroleum and Gas Industry 12, 27-39 (in Russian) [Карпов П.А., Чугунов Н.А., Воронков А.В., Доброквашин И.А., Прокофьев Н.А. Состав и физические свойства пород фундамента и малых интрузий палеопротерозойского возраста Волгоградской области // Труды Волгоград. НИИ нефт. и газ. промышленности. 1967. Вып. 12. С. 27-39].

Kolosovskaya V.A. (Ed.), 1992. Lithotectonic Map of the Crystalline Basement of southwestern East European Platform. In: Geology and Metallogeny of the southwestern East European Platform. Set of maps. Ukraine Goskomgeologia, Geoprognoz, Kiev [Колосовская В.А. (Ред.) Структурно-формационная карта кристаллического основания югозападной части Восточно-Европейской платформы // Геология и металлогения юго-западной части ВосточноЕвропейской платформы. Комплект карт. Киев: Госкомгеология Украины, Геопрогноз, 1992].

Kremenetsky A.A., Nenakhov V.M., Skryabin V.Yu., Polyakova T.N., Terent'ev R.A., Zolotareva G.S., 2007. Voronezh parametric borehole: A novelty from Voronezh Crystalline Massif. In: Basic problems of geotectonics. Proceedings of the 40th Tectonic Conference. Moscow, p. 360-363 (in Russian) [Кременецкий А.А., Ненахов В.М., Скрябин В.Ю., Полякова Т.Н., Терентьев Р.А., Золотарева Г.С. Воронежская параметрическая скважина: новое в геодинамической модели формирования Воронежского кристаллического массива (ВКМ) // Фундаментальные проблемы геотектоники: Материалы XL Тектонического совещания. М., 2007. С. 360-363].

Krestin E.M., 1975. Structure and formation conditions of Proterozoic volcanic formations in Kursk-Voronezh crystalline massif. In: Precambrian volcanism. Methods of paleovolcanic reconstructions. Petrozavodsk, p. 91-98 (in Russian) [Kpeстин E.M. Строение и условия формирования нижнепротерозойских эффузивных образований КурскоВоронежского кристаллического массива // Вулканизм докембрия. Методы палеовулканических реконструкций. Петрозаводск, 1975. С. 91-98].

Kryvdik S.G., Bocharov V.L., Levin V.N., 1987. Age correlation between Precambrian carbonatites of Ukrainian Shield and Voronezh Massif. In: Magmatism, metamorphism and geochronology of the Precambrian in East European Platform in connection with large-scale mapping. Abstracts. IV Regional Petrography Conference. Geological Institute of Karelian Branch of the USSR Academy of Sciences, Karelian Scientific Center, Petrozavodsk, p. 189-190 (in Russian) [Кривдuк С.Г., Бочаров В.Л., Левин В.Н. Возрастная информационная корреляция докембрийских карбонатитов Украинского щита и Воронежского массива // Магматизм, метаморфизм и геохронология докембрия ВосточноЕвропейской платформы в связи с крупномасштабным картированием: Тез. докл. IV регион. петр. совещ. Петрозаводск: ГИ Кар. ФАН СССР, 1987. С. 189-190].

Kryvdik S.G., Bezsmolova N.V., Dubina A.V., 2009. Alkaline magmatism of Peri-Azov region. Proceedings of UkrNDMI of NAS of Ukraine 5 (2), 158-166 (in Russian) [Кривдик С.Г., Безсмолова Н.В., Дубина А.В. Щелочной магматизм Приазовья // Наукові праці УкрНДМІ НАН України. 2009. № 5 (частина II). С. 158-166].

Lebedev I.P., 1972. On regional metamorphism of sandstone-shale sequence of Vorontsov series in the southeastern Voronezh crystalline massif. Geologichesky sbornik (Geological compilation). Proceedings of VSU 86, $56-60$ (in Russian) [Лебедев И.П. О региональном метаморфизме пород песчаниково-сланцевой толщи воронцовской серии в пределах юго-восточной части Воронежского кристаллического массива // Геологический сборник. Труды ВГУ. 1972. T. 86. C. 56-60].

Lobach-Zhuchenko S.B., Balagansky V.V., Aristov N.A., Sergeev S.A., Yurchenko A.V., Chekulaev V.P., Artemenko G.V., Presnyakov S.L., 2010a. U-Pb isotopic age of the rocks of Vasilkovsk locality in Orekhov-Pavlograd collision zone. Regionalnaya geologiya i metallogeniya (Regional geology and metallogeny) 43, 5-17 (in Russian) [Лобач-Жученко С.Б., Балаганский В.В., Аристова Н.А., Сергеев С.А., Юрченко А.В., Чекулаев В.П., Артеменко Г.В., Пресняков С.Л. Изотопный U-Pb возраст пород Васильковского района Орехово-Павлоградской коллизионной зоны // Региональная геология и металлогения. 2010b. № 43. С. 5-17].

Lobach-Zhuchenko S.B., Bibikova E.V., Balagansky V.V., Sergeev S.A., Artemenko G.V., Arestova N.A., Shcherbak N.P., Presnyakov S.L., 2010b. Paleoarchaean tonalites in the Orekhovo-Pavlogradskaya palaeoproterozoic collisional zone (Ukrainian Shield). Doklady Earth Sciences 433 (1), 873-878. http://dx.doi.org/10.1134/S1028334X10070068.

Marchenko E.Y., Strekozov S.N., 1999. Precambrian ore-bearing structure of the Peri-Azov Region. Mineral resources of Ukraine (1), 34-36 (in Russian) [Марченко Е.Я., Стрекозов С.Н. Азовская рудоносная докембрийская структура Приазовья // Мінеральні ресурси Украіни. 1999. № 1. С. 34-36].

Meissner R., 1989. Rupture, creep, lamellae and crocodiles: happenings in the continental crust. Terra Nova 1 (1), 17-28. http://dx.doi.org/10.1111/j.1365-3121.1989.tb00321.x. 
Mints M.V., 2011. 3D model of deep structure of the Early Precambrian crust in the East European Craton and paleogeodynamic implications. Geotectonics 45 (4), 267-290. http://dx.doi.org/10.1134/S0016852111040054.

Mints M.V., 2014. Tectonics and geodynamics of granulite-gneiss complexes in the East European Craton. Geotectonics 48 (6) (in press).

Mints M.V., Suleimanov A.K., Babayants P.S., Belousova E.A., Blokh Yu.I., Bogina M.M., Bush W.A., Dokukina K.A., Zamozhniaya N.G., Zlobin V.L., Kaulina T.V., Konilov A.N., Mikhailov V.O., Natapov L.M., Piip V.B., Stupak V.M., Tihotsky S.A., Trusov A.A., Philippova I.B., Shur D.Yu., 2010. Deep structure, evolution and mineral deposits of the Early Precambrian basement of the East European platform: an interpretation of the data from 1-EU geotraverse, the 4B and Tatseis profiles. GEOKART, GEOS, Moscow, V. 1. 408 p., V. 2. 400 p. (in Russian) [Минц М.В., Сулейманов А.К., Бабаянц П.С., Белоусова Е.А., Блох Ю.И., Богина М.М., Буш В.А., Докукина К.А., Заможняя Н.Г., Злобин В.Л., Каулина Т.В., Конилов А.Н., Михайлов В.О., Натапов Л.М., Пийп В.Б., Ступак В.М., Тихоцкий С.А., Трусов А.А., Филиппова И.Б., Шур Д.Ю. Глубинное строение, эволюция и полезные ископаемые раннедокембрийского фундамента Восточно-Европейской платформы: Интерпретация материалов по опорному профилю 1-ЕВ, профилям 4В и Татсейс. 2010. Т 1. 408 с., Т. 2. 400 с.].

Mints M., Suleimanov A., Zamozhniaya N., Stupak V., 2009. A three-dimensional model of the Early Precambrian crust under the southeastern Fennoscandian Shield: Karelia Craton and Belomorian tectonic province. Tectonopysics 472 (1-4), 323339. http://dx.doi.org/10.1016/j.tecto.2008.12.008.

Molotkov S.P. et al., 1999. Geological Map of the Voronezh Crystalline Massif, scale 1:500000: Yugnedra, Voronezh (in Russian) [Молотков С.П. и др. Геологическая карта Воронежского кристаллического массива масштаба 1:500000. Воронеж: Югнедра, 1999].

Nozhkin A.D., Krestin E.M., 1984. Radioactive Elements in Early Precambrian Rocks. Nauka, Moscow, 126 p. (in Russian) [Ножкин А.Д., Крестин Е.М. Радиоактивные элементы в породах раннего докембрия. М.: Наука, 1984. 126 с.].

Pigulevsky P.I., 2012. Structure and metallogeny of the crust and upper mantle of the eastern Ukrainian shield on the results of complex geological and geophysical studies. Author's abstract of DSc. Kiev: Taras Shevchenko National University of Kyiv, 40 p. (in Russian) [Пигулевский П.И. Строение и минерагения земной коры и верхней мантии восточной части Украинского щита по результатам комплексных геолого-геофизических исследований: Автореф. дис. ... докт. геол.-мин. наук. Киев: КНУ им. Т.Шевченко, 2012. 40 с.].

Plaksenko N.A., Chernyshov N.M., Shchegolev I.N., Blagonadezhdin B.I., 1980. Precambrian metallogeny of the Voronezh Crystalline Massif. In: Precambrian regional metallogeny of the USSR. Nauka, Leningrad, p. 21-28 (in Russian) [Плаксенко Н.А., Чернышов Н.М., Щеголев И.Н., Благонадеждин Б.И. Металлогения докембрия Воронежского кристаллического массива // Региональная металлогения докембрия СССР. Л.: Наука, 1980. С. 21-28].

Polishchuk V.D., Golivkin N.I., Zaitsev Yu.S., Klagish B.D., Polishchuk V.I., Pavlovsky V.I., Krasovitskaya R.S., 1970. Geology, Hydrogeology, and Iron Ores in Basin of the Kursk Magnetic Anomaly, Vol. 1: Geology, Book 1: Precambrian. Nedra, Moscow, 440 p. (in Russian) [Полищук В.Д., Голивкин Н.И., Зайцев Ю.С., Клагиш Б.Д., Полищук В.И., Павловский В.И., Красовицкая Р.С. Геология, гидрогеология и железные руды бассейна Курской магнитной аномалии. Т. 1. Геология. Кн. первая. Докембрий. М.: Недра, 1970. 440 с.].

Raskatov G.I., Lukyanov V.F., Starukhin A.A., Sychev I.A., Kholmova G.V., Shishoff V.V., 1976. Tectonics of the Eastern Voronezh Crystalline Massif and Its Sedimentary Cover. VSU, Voronezh, 120 p. (in Russian) [Раскатов Г.И., Лукьянов В.Ф., Старухин А.А., Сычев И.А., Холмовой Г.В., Шишов В.В. Тектоника восточной части Воронежского кристаллического массива и его осадочного чехла. Воронеж: ВГУ, 1976. 120 с.].

Rosen O.M., Abbyasov A.A., Aksamentova N.V., Bredanova N.V., Zlobin V.L., Migdisov A.A., Safronov V.T., Tolkachikova A.A., Trusov A.I., Chekhovich P.A., Yaroshevsky A.A., 2006. Early Precambrian Sedimentation: Types of Sediments, Metasedimentary Basins, and Evolution of Terrigenous Rocks: Nauchnyi Mir, Moscow, 400 p. (in Russian) [Розен О.M., Аббясов А.А., Аксаментова Н.В., Бреданова Н.В., Злобин В.Л., Мигдисов А.А., Сафронов В.Т., Толкачикова А.А., Трусов А.И., Чехович П.А., Ярошевский А.А. Седиментация в раннем докембрии: типы осадков, метаморфизованные осадочные бассейны, эволюция терригенных отложений (Труды ГИН РАН, вып. 569). М.: Научный Мир, 2006. 400 c.].

Rundquist D.V., Mints M.V., Larin A.M., Nenakhov V.M., Rytsk E.Yu., Turchenko S.И., Chernyshov N.M., 1999. Metallogeny of Early Precambrian Geodynamic Settings. Geokart, Moscow, 399 p. (in Russian) [Рундквист Д.В., Минц М.В., Ларин А.М., Ненахов В.М., Рыцк Е.Ю., Турченко С.И., Чернышов Н.М. Металлогения рядов геодинамических обстановок раннего докембрия. М.: МПР РФ, РАН, Геокарт, 1999. 399 с.].

Sarkisova N.P., 2001. State Geological Map of the Russian Federation. M-37, (38) (Voronezh). Scale 1:1000000 (Ed. M.S Shik). Ministry of Natural Resources (in Russian) [Саркисова Н.П. Государственная геологическая карта Российской Федерации. М-37, (38) (Воронеж). Масштаб 1: 1000000. МПР РФ, 2001].

Savko K.A., 1999. Granulites of the Voronezh Crystalline Massif: Petrology and Evolution of Metamorphism. Voronezh State University, Voronezh, 130 p. (in Russian) [Савко К.А. Гранулиты Воронежского кристаллического массива: петрология и эволюция метаморфизма. Воронеж: Воронежский госуниверситет, 1999. 130 с.].

Savko K.A., Gerasimov V.Yu., 2002. Petrology and Geospeedometry of Metamorphic Rocks in the eastern Voronezh Crystalline Massif. Voronezh State University, Voronezh, 131 p. (in Russian) [Савко К.А., Герасимов В.Ю. Петрология и геоспидометрия метаморфических пород востока Воронежского кристаллического массива. Воронеж: Воронежский госуниверситет, 2002. 131 с.]. 
Savko K.A., Kal'mutskaya I.Yu., 2001. The olivine-gedrite-orthopyroxene-garnet-magnetite assemblage in K-undersaturated schists of the Voronezh Crystalline Massif. Vestnik Voronezhskogo Universiteta. Geologiya (Voronezh University Bulletin. Geology) 11, 115-121 (in Russian) [Савко К.А., Кальмуцкая И.Ю. Минеральная ассоциация оливин-жедритортопироксен-гранат-магнетит в недосыщенных калием сланцах Воронежского кристаллического массива // Вестник Воронежского университета. Геология. 2001. Вып. 11. С. 115-121].

Savko K.A., Khiller V.V., Bazikov N.S., Votyakov S.L., 2012. Th-U-Pb age of metamophism of the Vorontsovka group rocks, Voronezh crystalline massif, from microbrobe dating of monazites. Doklady Earth Sciences 444 (1), 568-573. http://dx.doi.org/10.1134/S1028334X12050194.

Savko K.A., Polyakova T.N., 2000. Types of zoning in garnets and metamorphic evolution of metapelites in the TimYastrebovka structure, Voronezh Crystalline Massif. Vestnik Voronezhskogo Universiteta. Geologiya (Voronezh University Bulletin. Geology) 10, 64-79 (in Russian) [Савко К.А., Полякова T.Н. Типы зональности гранатов и метаморфическая эволюция метапелитов Тим-Ястребовской структуры, Воронежский кристаллический массив // Вестник Воронежского университета. Геология. 2000. Вып. 10. С. 64-79].

Savko K.A., Poskryakova M.V., 2003. Mineralogy, phase equilibria, and conditions of metamorphism of rocks at the Novoyaltinsky iron deposit, KMA. Vestnik Voronezhskogo Universiteta. Geologiya (Voronezh University Bulletin. Geology) (2), 113-131 (in Russian) [Савко К.А., Поскрякова М.В. Минералогия, фазовые равновесия и условия метаморфизма пород Новоялтинского железорудного месторождения КМА // Вестник Воронежского университета. Геология. 2003. № 2. С. 113-131].

Savko K.A., Poskryakova M.V., and Lebedev I.P, 2003. Phase equilibria and physicochemical metamorphic conditions of BIF at Pankovo deposit, the Kursk magnetic anomaly. Vestnik Voronezhskogo Universiteta. Geologiya (Voronezh University Bulletin. Geology) (1), 58-71 (in Russian) [Савко К.А., Поскрякова М.В., Лебедев И.П. Фазовые равновесия и физико-химические условия метаморфизма пород железисто-кремнистой формации Панковского месторождения Курской магнитной аномалии // Вестник Воронежского университета. Геология. 2003. № 1. С. 58-71].

Shcherbak N.P., Artemenko G.V., Bartnitsky E.N., Sergienko V.N., Tatarinova E.I., 1992. Age of felsic metavolcanic rocks in the Aleksandrovo and Korobkovo areas of KMA. Doklady NAN Ukraini (Transactions of Ukranian Academy of Sciences) (6), 120-123 (in Russian) [Щербак Н.П., Артеменко Г.В., Бартницкий Е.Н., Сергиенко В.Н., Татаринова Е.И. Возраст кислых метавулканитов Александровского и Коробковского участков КМА // Доклады НАН Украины. 1992. № 6. С. 120-123].

Shcherbak N.P., Artemenko G.V., Bartnitsky E.N., Verkhoglyad V.M., Komaristy A.A., Lesnaya I.M., Mitscevich N.Y., Ponomarenko A.R., Scobelev V.M., Shcherbak D.R., 1989. Geochronologic Scale of Precambrian in the Ukrainian Shield. Naukova Dumka, Kiev, 144 p. (in Russian) [Щербак Н.П., Артеменко Г.В., Бартницкий Е.Н., Верхогляд В.М., Комаристый А.А., Лесная И.М., Мицкевич Н.Ю., Пономаренко А.Р., Скобелев В.М., Щербак Д.Р. Геохронологическая шкала докембрия Украинского щита. Киев: Наукова Думка, 1989. 144 с.].

Shcherbak N.P., Bibikova E.V., Lobach-Zhuchenko S.B., Artemenko G.V., Presnyakov S.L., 2009. Paleoarhean in the eastern Ukrainian Shield according to U-Pb method (3.6-3.2 Ga). Myneralogichny Zhurnal (Mineralogical Journal) 31 (3), 3-9. (in Russian) [Щербак Н.П., Бибикова Е.В., Лобач-Жученко С.Б., Артеменко Г.В., Пресняков С.Л. Палеоархей восточной части Украинского щита по данным U-Pb метода (3.6-3.2 млрд лет) // Минералогічний журнал. 2009. T. 31. № 3. С. 3-9].

Shcherbakov I.B., 2005. Petrology of the Ukrainian Shield. ZUKC, Lvov, 366 p. (in Russian) [Щербаков И.Б. Петрология Украинского щита. Львов: ЗУКЦ, 2005. 366 с.].

Shchipansky A.A., Bogdanova S.V., 1996. The Sarmatian crustal segment: Precambrian correlation between the Voronezh Massif and the Ukrainian Shield across the Dniepr-Donets Aulacogen. Tectonophysics 268 (1-4), 109-125. http://dx. doi.org/10.1016/S0040-1951(96)00227-2.

Shchipansky A.A., Samsonov A.V., Petrova A.Yu., Larionova Yu.O., 2007. Geodynamics of the eastern margin of Sarmatia in the Paleoproterozoic. Geotectonics, 41 (1), 38-62. http://dx.doi.org/10.1134/S0016852107010050.

Stovba C.N., Tolkunov A.P., Maystrenko Yu.P., Stephenson R.A., Baer U., Gajevsky D., Rabbel V., Starostenko V.I., Tibo G., 2006. Deep study along DOBRE CMP profile. In: Structure and dynamics of the lithosphere of Eastern Europe. Research results under EUROPROBE Program. Issue 2. Geokart, Moscow, p. 328-332 (in Russian) [Стовба С.Н., Толкунов А.П., Майстренко Ю.П., Стифенсон Р.А., Баер У., Гаевский Д., Раббель В., Старостенко В.И., Тибо Г. Глубинные исследования по профилю DOBRE методом ОГТ // Строение и динамика литосферы Восточной Европы. Результаты исследований по программе EUROPROBE. М.: ГЕОКАРТ, ГЕОС, 2006. С. 328-332].

Teixell A., 1998. Crustal structure and orogenic material budget in the west central Pyrenees. Tectonics 17 (3), 395-406. http://dx.doi.org/10.1029/98TC00561.

Terent'ev R.A., 2002. Metavolcanics of Losevka series and their formational type (Voronezh crystalline massif). Vestnik Voronezhskogo Universiteta. Geologiya (Voronezh University Bulletin. Geology) (1), 140-150 (in Russian) [Терентьев P.A. Метавулканиты лосевской серии и их формационная принадлежность (Воронежский кристаллический массив) // Вестник Воронежского университета. Геология. 2002. № 1. С. 140-150].

Tugariniov A.I., Bibikova E.V., Zykov S.I., 1964. Absolute age of rocks from KMA. Geokhimiya (Geochemistry) 2 (10), 988994 (in Russian) [Тугаринов А.И., Бибикова Е.В., Зыков С.И. Абсолютный возраст горных пород КМА // Геохимия. 1964. № 10. C. 988-994].

Vasilchenko V.V., Kiselev V.A., Zagnitko V.N., 1992. Charnockitoids of the Eastern Peri-Azov area. Geologichesky Zhurnal (Geological Journal) (1), 27-34 (in Russian) [Васильченко В.В., Киселев В.А., Загнитко В.Н. Чарнокитоиды Восточного Приазовья // Геологический журнал. 1992. № 1. С. 27-34]. 
Yatsenko G.M., Gursky D.S., Slivko E.M. et al., 2002. Diamondiferous Formations and Structures of the Southwestern Margin of the East European Platform. UkrGGRI, Kiev, 331 p. (in Russian) [Яценко Г. М., Гурский Д. С., Сливко Е. М. и др. Алмазоносные формации и структуры юго-западной окраины Восточно-Европейской платформы. Киев: УкрГГРИ, 2002. 331 с.].

Yesipchuk K.E., Sheremet E.M., Zinchenko O.V. et al., 1990. Petrology, geochemistry and metallogeny of intrusive granitoids of the Ukrainian Shield. Naukova Dumka, Kiev, 236 p. (in Russian) [Есипчук K.Е., Шеремет Е.М., Зинченко О.В. и др. Петрология, геохимия и рудоносность интрузивных гранитоидов Украинского щита. Киев: Наукова Думка, 1990. 236 c.].

Zagnitko V.N., Lugovaya I.P., 1989. Isotope Geochemistry of Carbonate and Ferruginous-Siliceous Rocks of the Ukrainian Shield. Naukova Dumka, Kiev, 316 p. (in Russian) [Загнитко В.Н., Луговая И.П. Изотопная геохимия карбонатных и железисто-кремнистых пород Украинского щита. Киев: Наукова Думка, 1989. 316 с.].

Zaitsev Yu.S., 1966. Mikhailovka series in the Belgorod iron-ore region and some questions Precambrian stratigraphy in Voronezh anticline. In: Transactions of the Third Conference on problems of the Voronezh anticline. VGU, Voronezh, p. 21-28 (in Russian) [Зайцев Ю.С. Михайловская серия Белгородского железорудного района и некоторые вопросы стратиграфии докембрия Воронежской антеклизы // Тр. Третьего совещания по проблемам изучения Воронежской антеклизы. Воронеж: ВГУ, 1966. С. 21-28].

Zaitsev Yu.S., Ivanov A.V., Lebedev I.P., 1978. Early Precambrian metamorphic complexes in the southeastern Voronezh Crystalline Massif. In: Metamorphic complexes in basement of the Russian plate. Nauka, Leningrad, 115-130 (in Russian) [Зайцев Ю.С., Иванов А.В., Лебедев И.П. Метаморфические комплексы раннего докембрия юго-восточной части Воронежского кристаллического массива // Метаморфические комплексы фундамента Русской плиты. Л.: Наука, 1978. С. 115-130].
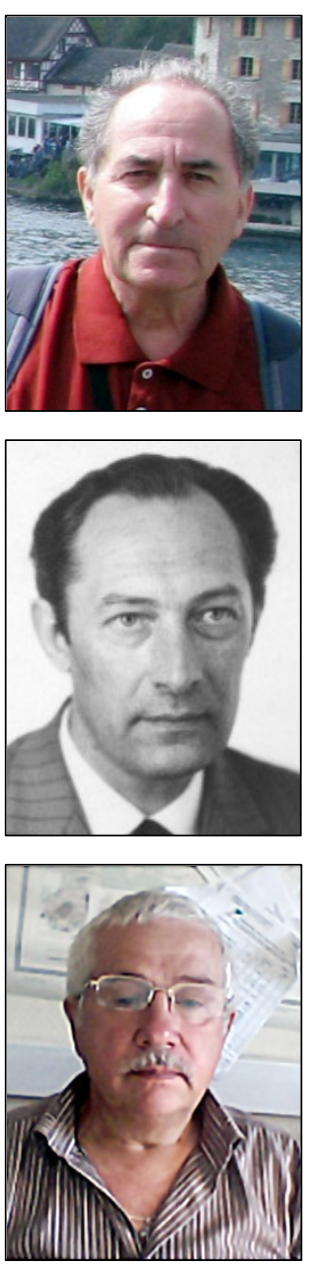

Минц Михаил Вениаминович, докт. геол.-мин. наук, зав. лабораторией Геологический институт РАН 119016, Москва, Пыжевский пер., 7, Россия

凶 e-mail: michael-mints@yandex.ru

Mints, Mikhail V., Doctor of Geology and Mineralogy, Head of laboratory Geological Institute of RAS

7 Pyzhevsky lane, Moscow 119017, Russia

\e-mail: michael-mints@yandex.ru

Буш Вильям Артурович, докт. геол.-мин. наук

ЗАО ГНПП «Аэрогеофизика»

127287, Москва, 2-я Хуторская ул., 38А, стр. 15, Россия

e-mail: bush@aerogeo.ru

Bush, William A., Doctor of Geology and Mineralogy

Aerogeophysica Inc.

38/A building 15 2-nd Khutorskaya street, Moscow 127287, Russia

e-mail: bush@aerogeo.ru

\section{Агеев Сергей Николаевич}

ЗАО ГНПП «Аэрогеофизика»

127287, Москва, 2-я Хуторская ул., 38А, стр. 15, Россия

e-mail:7777@inbox.ru

\section{Ageev, Sergei N.}

Aerogeophysica Inc.

38/A building 15 2-nd Khutorskaya street, Moscow 127287, Russia

e-mail: 7777@inbox.ru 